J. Lake Sci. (湖泊科学), 2021, 33(1): 86-101

DOI 10. 18307/2021. 0114

(c) 2021 by Journal of Lake Sciences

\title{
西藏巴松错浮游植物功能群垂直分布特征及其与环境因子的关系”
}

\author{
安瑞志 ${ }^{1}$, 潘成梅 $^{1}$, 塔巴拉珍 ${ }^{2}$, 杨欣兰 $^{3}$,巴 桑 ${ }^{1 * *}$ \\ (1: 西藏大学理学院青藏高原湿地与流域生态实验室, 拉萨 850000) \\ (2: 西藏自治区昌都市卡若区约巴乡乃通村教学点,昌都 854000) \\ (3:西藏农牧科学院水产科学研究所, 拉萨 850032)
}

\begin{abstract}
摘 要: 为了解青藏高原湖泊浮游植物功能群垂直分布特征与环境因子的关系, 本文选取西藏东南部最大的高山冰川堰 塞湖之一的巴松错为研究对象, 于 2017 年 11 月 (枯水期) 和 2018 年 9 月 (丰水期) 在湖心利用挂锤式深水采样器进行浮 游植物垂直分层采样, 共设置 7 个断面, 采集水样 84 个. 应用浮游植物功能群、相关性分析、攵余分析 (RDA) 等方法, 对 巴松错浮游植物功能群垂直分布特征及其与环境因子的关系进行了研究. 结果表明: 1) 巴松错水体稳定性强, 水温有明 显的分层现象, 枯水期在 30 60 m 处形成温跃层, 丰水期在 1 15 m 和 30 60 m 处形成双温跃层;2) 巴松错浮游植物群 落共鉴定 7 门 76 属 242 种, 物种组成均表现为硅藻一蓝藻一绿藻型结构; 3 ) 根据浮游植物功能群分类方法, 可划分为 25 个功能群, 分别为 $A 、 B 、 C 、 D 、 E 、 F 、 G 、 H 1 、 H 2 、 J 、 L_{M} 、 L_{0} 、 M 、 M P 、 N 、 P 、 S 1 、 S 2 、 T 、 W 1 、 W 2 、 X 1 、 X 2 、 X 3$ 和 $Y$, 优势功能群从枯 水期的 MP、 $D 、 L_{0} 、 P$ 转变为丰水期的 $D 、 F 、 L_{0} 、 M P 、 N 、 P$, 其中 $M P$ 功能群为巴松错浮游植物群落绝对优势群; 4$)$ 通过 $R D A$ 表明, 不同水情期浮游植物功能群垂直分布特征受环境因子影响差异较明显, 整体上, $\mathrm{pH}$ 、总氮和氨氮浓度是影响浮游植 物功能群分布格局的主要环境因子.
\end{abstract}

关键词: 巴松措; 浮游植物;功能群;环境因子;垂直分布

\section{Vertical distribution characteristics of phytoplankton functional groups and their relation- ships with environmental factors in Lake Basomtso, Tibet, China*}

\author{
An Ruizhi ${ }^{1}$, Pan Chengmei $^{1}$, Taba Lazhen ${ }^{2}$, Yang Xinlan ${ }^{3} \&$ Ba Sang $^{1 * *}$ \\ (1: Laboratory of Wetland and Catchments Ecology in Tibetan Plateau, Faculty of Natural Sciences, Tibet University, Lhasa \\ 850000, P.R.China) \\ (2: Teaching Site of Naitong Village, Yueba Township, Kharo District, Qamdo City, Tibet Autonomous Region, Qamdo \\ 854000, P.R.China) \\ (3: Institute of Fisheries Science, Tibet Academy of Agriculture and Animal Husbandry, Lhasa 850032, P.R.China)
}

Abstract: In order to understand vertical distribution characteristics of phytoplankton functional groups and their relationships with
environmental factors in the lakes of the Qinghai-Tibet plateau, this paper takes Lake Basomtso, which is one of the biggest alpine
glacier lakes in southeast Tibet, as the research object, a total of 84 samples were collected from seven vertical stratifications by u-
sing vertical stratified sampling of phytoplankton in the center of the lake with hammer hung deep water samplers in the dry ( No-
vember 2017) and wet ( September 2018 ) seasons. Using the methods of phytoplankton functional group, correlation analysis and
redundancy analysis ( RDA), the vertical distribution characteristics among functional groups of phytoplankton in Lake Basomtso
and its relationship with environmental factors were studied. The results showed that: 1 ) Lake Basomtso exhibited highly water sta-
ble, and the water temperature is obviously stratified. The thermocline is located at a water depth of $30-60 \mathrm{~m}$ in the dry season,
and the double thermocline is located at a water depth of $1-15 \mathrm{~m}$ and $30-60 \mathrm{~m}$ in the wet season. 2) The phytoplankton community
in Lake Basomtso was identified with 242 species from 7 families, 76 genera, and the species composition was bacillariophyta-cya-

* 2020-04-14 收稿; 2020-05-23 收修改稿.

国家自然科学基金项目(31660620)和 2019 年中央支持地方高校发展专项资金项目(藏财教指 [ 2019]01 号)联合 资助.

** 通信作者; E-mail:hbasang2003@ aliyun.com. 
nophyta-chlorophyta. 3) According to the functional group classification method of the phytoplankton, it can be divided into 25 functional groups, respectively, A, B, C, D, E, F, G, H1, H2, J, MP, LM, L , M, N, P, S1, S2, T, W1, W2, X1, X2, $\mathrm{X} 3$ and $\mathrm{Y}$, the dominant function groups change from MP, D, $\mathrm{L}_{\mathrm{O}}$ and $\mathrm{P}$ in the dry season to $\mathrm{D}, \mathrm{F}, \mathrm{L}_{\mathrm{O}}, \mathrm{MP}, \mathrm{N}$ and $\mathrm{P}$ in the wet season; MP functional group is the absolute dominant group of phytoplankton community in Lake Basomtso. 4) RDA results showed that the vertical distribution characteristics of phytoplankton functional groups were significantly affected by environmental factors in the different water regimen periods. On the whole, $\mathrm{pH}$, total nitrogen and ammonia nitrogen were the main environmental factors affecting the distribution pattern of phytoplankton functional groups.

Keywords: Lake Basomtso; phytoplankton; functional group; environmental factors; vertical distribution

浮游植物作为湖泊生态系统中初级生产者的重要组成部分和生态指示性类群, 其生物量、物种组成、优 势种以及多样性能直接反映湖泊水质的状况 ${ }^{[1]}$. 但常规传统的系统分类学难以体现浮游植物在湖泊生态系 统中的生态特征和生境类型, 国内外学者便将具有相同或相近的生态位的优势种组合定义为功能群, 以生 理生长特征和生态适应性为基础, 把生理、形态和生存策略相似或相同的浮游植物归为一个功能群, 作为浮 游植物对生境变化的响应的基本单元 ${ }^{[2]}$. Reynolds 等 ${ }^{[3]}$ 第一次划分出 31 个浮游植物功能群,Padisák 等 ${ }^{[4]}$ 基 于此修正, 至今共鉴定划分了 39 个功能群. 迄今国内外研究功能群在湖泊浮游植物生态学方面应用的报道 日益增多 ${ }^{[5-7]}$. 然而有关青藏高原湖泊浮游植物功能群方面的相关研究鲜有报道.

青藏高原湖泊分布众多而密集, 其面积约为 $5 \times 10^{4} \mathrm{~km}^{2}$, 占全球湖泊总面积的 $1.9 \%$, 在维持“亚洲水塔” 区域水平衡和水循环中起着重要作用 ${ }^{[8]}$. 西藏受人类活动干扰较小, 大部分湖泊生态系统保持着相对原始 的自然状态, 对气候变化十分敏感, 逐步成为研究生物起源、进化、区系和迁徙的理想选择,得到国内外研究 学者的广泛关注 ${ }^{[9-12]}$. 巴松错属雅鲁藏布江支流尼洋河水系, 在维持该区域生态平衡、调节气候、保持生物多 样性和提高居民生产、生活等方面起着重要作用. 至今有关巴松错的生物学研究主要集中在浮游动物和真 菌等方面 ${ }^{[13-14]}$, 有关浮游植物的研究相对较少 ${ }^{[15]}$.

为了解青藏高原湖泊浮游植物功能群垂直分布特征与环境因子的关系, 本文选取西藏东南部最大的高 山冰川堰塞湖之一——松错为研究对象,于 2017 年 11 月 (枯水期) 和 2018 年 9 月 (丰水期) 在巴松错进 行了定性和定量样品采集, 共采集水样 84 个, 利用功能群的方法对巴松错浮游植物进行划分, 对该湖泊浮 游植物功能群与水环境的相关性进行了研究, 旨在探索巴松错浮游植物群落与环境因子的变化规律, 为研 究巴松错生态系统和管理提供基础资料.

\section{1 材料与方法}

\section{1 样区概况和样点设置}

巴松错位于尼洋河最大支流巴河的宽谷中, 是西藏东南部最大的高山冰川堰塞湖之一, 湖面海拔 3469 $\mathrm{m}$, 最大湖深约为 $120 \mathrm{~m}$, 湖泊面积 $25.9 \mathrm{~km}^{2}$, 流域面积 $1290 \mathrm{~km}^{2}$, 年均人湖流量 $17 \times 10^{8} \mathrm{~m}^{3[16]}$, 蓄水量 $3.5 \times$ $10^{8} \mathrm{~m}^{3[17]}$. 湖泊所在区域属于典型的高原温带半湿润季风气候, 年均降水量 $646 \mathrm{~mm}$, 主要集中在 4- 10 月, 年平均气温 $6.3^{\circ} \mathrm{C}$, 年无霜期 $175 \mathrm{~d}$, 年日照时数为 $2016 \mathrm{~h}^{[18]}$. 根据以上资料可以得出,巴松错属于深水 湖泊. 相较于浅水湖泊, 深水湖泊容易受到季节变化 影响而形成稳定的水温分层现象 ${ }^{[19]}$. 基于此, 本研 究在巴松错湖心区 $M\left(30^{\circ} 01^{\prime} 06.04^{\prime \prime} \mathrm{N}, 93^{\circ} 55^{\prime} 39.95^{\prime \prime}\right.$ $\mathrm{E})$, 采用传统挂锤式测得最大水深为 $108 \mathrm{~m}$, 采样时 间为 2017 年 11 月 (枯水期) 和 2018 年 9 月 (丰水 期), 依次按水深 $0.5 \mathrm{~m}$ (M1) 、2.5 m(M2)、 $5 \mathrm{~m}$ (M3)、 $15 \mathrm{~m}$ (M4)、30 m( M5)、60 m( M6) 和 $100 \mathrm{~m}$ ( M7) 共 7 个分层(图 1) 进行垂直分层采样.

\section{2 水样采集、处理及鉴定方法}

采用挂锤式深水采样器进行分层采集水样, 分

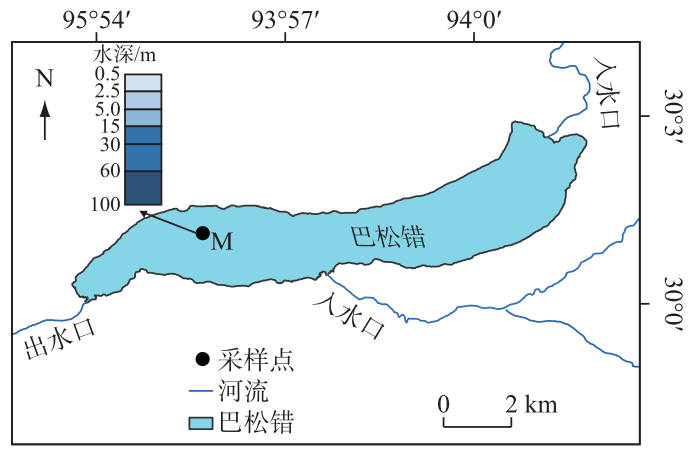

图 1 巴松错采样点位置

Fig. 1 Location of sampling sites in Lake Basomtso 
别将有机玻璃采水器与卡盖式采水器 ( QCC15) 置于相应水深, 静置 5 10 min 后, 采得水样, 并设置 3 个平 行; 浮游植物的定性和定量样品采集均按照上述方法进行, 其中 $1 \mathrm{~L}$ 水样用于定性分析, 观察活体; $1 \mathrm{~L}$ 水样 用于定量样品, 现场立即用鲁哥氏碘液固定, 静置沉淀 $48 \mathrm{~h}$ 后, 用虹吸法定容至 $30 \mathrm{~mL}$, 充分摇匀后吸取 0.1 $\mathrm{mL}$ 浓缩匀液于 $0.1 \mathrm{~mL}$ 计数框内镜检计数 ${ }^{[20]}$. 在 OLYMPUS CX41 显微镜下进行物种鉴定, 藻类鉴定参考经 典文献 ${ }^{[21-24]}$. 浮游植物生物量利用合适的体积公式将浮游植物丰度转化为生物量 (鲜重), 并假设其比重为 1.0 , 即生物量为浮游植物的丰度乘以各自体积的平均湿重 ${ }^{[25-27]}$.

现场采用赛氏盘测量水体透明度 (SD), 用 PCSTestr35 防水型多参数笔试测试仪 (EUTECH, 美国) 现场 测定水体 $\mathrm{pH}$ 、水温 (WT)、电导率 (EC)、盐度 (Salt) 及总溶解盐 (TDS) 浓度; 用 HI98193 微电脑溶解氧测定 仪 (HANNA, 意大利) 测定溶解氧 (DO) 浓度; 用 HI98703 微电脑多量程浊度测定仪 (HANNA, 意大利) 测得 浊度 (TUR) 等,并进行 3 次平行检测取其平均值; 严格按照国家《地表水环境质量标准》(GB3838-2002)对 水样进行采集、保存与运输, 送有检测资质公司对水体总磷 $(\mathrm{TP})$ 、总氮 $(\mathrm{TN})$ 、氨氮 $\left(\mathrm{NH}_{3}-\mathrm{N}\right)$ 、五日生物需氧 量 $\left(\mathrm{BOD}_{5}\right)$ 和重铬酸盐指数 $\left(\mathrm{COD}_{\mathrm{Cr}}\right)$ 等指标进行测定.

\section{3 计算}

水体相对稳定性 (RWCS) 是评价水体混合程度及分层状态的参数. 水体稳定性越大, 越易发生分层; 水 体稳定性越小, 越易发生混合. 对于分层型湖库, 通过比较底层 $\left(D_{\mathrm{h}}\right)$ 和表层 $\left(D_{\mathrm{s}}\right)$ 水的密度差异和水体在 $4^{\circ} \mathrm{C}\left(D_{4}\right)$ 和 $5^{\circ} \mathrm{C}\left(D_{5}\right)$ 时的密度差异, 根据 Padisák 等 ${ }^{[28]}$ 的公式计算 $R W C S$, 为更详细、精确地计算湖库的水 体相对稳定性,对公式进行改进,计算公式为:

$$
\begin{gathered}
R W C S=\frac{D_{\mathrm{h}}-D_{\mathrm{s}}}{D_{4}-D_{5}} \\
R W C S=\sqrt{\frac{1}{n} \sum_{i=1}^{n} R W C S_{i}^{2}} \\
R W C S_{i}=\frac{D_{\mathrm{hi}}-D_{\mathrm{s} i}}{D_{4}-D_{5}}
\end{gathered}
$$

式中, $D_{h i}$ 和 $D_{s i}$ 分别为第 $i \mathrm{~m}$ 底层温度和表层温度下的水体密度, $D_{4}$ 和 $D_{5}$ 分别代表 4 和 $5^{\circ} \mathrm{C}$ 下的水体密度, $R W C S_{i}$ 为第 $i \mathrm{~m}$ 水体稳定性.

水体密度通过 Krambeck 方程进行计算 ${ }^{[29]}$ :

$$
\rho=0.999869+6.67413 \times 10^{-5} W T-8.85556 \times 10^{-6} W T^{2}+8.23031 \times 10^{-8} W T^{3}-5.51577 \times 10^{-10} W T^{4}
$$

式中, $W T$ 表示水温.

本文中以 $\geqslant 0.1^{\circ} \mathrm{C} / \mathrm{m}$ 的温度梯度为温跃层深度 ${ }^{[30]}$, 以透明度的 2.7 倍所对应的深度作为真光层深度 $\left(Z_{\mathrm{eu}}\right)^{[31]}$, 以表层水温改变 $\geqslant 0.5^{\circ} \mathrm{C}$ 时所对应的深度作为混合层深度 $\left(Z_{\text {mix }}\right)^{[32]}$, 可采用温度曲线进行估计, 并以此为温跃层的上界深度, 真光层与混合层的比率 $\left(Z_{\mathrm{eu}} / Z_{\text {mix }}\right)$ 则作为水体光的可利用性评判标准 ${ }^{[33]}$.

为了避免单一多样性指数造成结果偏差, 利用 Gleason-Margalef 丰富度指数 $\left(D_{\mathrm{m}}\right)^{[34]}$ 、Shannon-Wiener 多 样性指数 $\left(H^{\prime}\right)^{[35]}$ 和 Simpson 优势度指数 $\left(D_{\mathrm{s}}\right)^{[36]}$ 这 3 个指数来计算巴松错浮游植物的生物多样性. 计算公 式为:

$$
\begin{gathered}
D_{\mathrm{m}}=\frac{S-1}{\ln N} \\
H^{\prime}=-\sum_{i=1}^{S}\left(P_{i} \cdot \ln P_{i}\right) \\
D_{\mathrm{s}}=1-\sum_{i=1}^{S}\left(P_{i}\right)^{2}
\end{gathered}
$$

式中, $S$ 为采样点的物种数; $N$ 为采样点所有浮游植物的细胞丰度; $P_{i}$ 为第 $i$ 种个体所占的比例.

$Q$ 指数由 Padisák 公式确定 ${ }^{[4]}$ :

$$
Q=\sum_{i=1}^{S}\left(P_{i} \cdot F_{i}\right)
$$


式中, $S$ 为浮游植物功能群的数量, $P_{i}$ 为第 $i$ 功能群生物量占总生物量的比例, $F_{i}$ 为第 $i$ 个功能群的赋值. $Q$ 指数为 $0 \sim 5$ 时分别表示: $0 \sim 1$ 差; $1 \sim 2$ 耐受; $2 \sim 3$ 中等; $3 \sim 4$ 好; $4 \sim 5$ 极好.

\section{4 数据处理与分析}

采用 Excel 2016 和 OriginPro 2019 软件进行数据分析、统计和绘图,采用 ArcGIS 软件绘制地图. 用 $\mathrm{R} \times$ 64 3.6.2 进行多响应置换过程 (multi response permutation procedure, MRPP). 对巴松错浮游植物功能群进行 篮选 (该功能群的相对生物量至少在一个采样点大于 $10 \%$, 即表明为优势功能群), 将优势功能群生物量和 环境因子数据均进行 $\lg (x+1)$ 转换. 优势功能群生物量与环境因子用 SPSS 26.0 软件进行相关性分析, 并结 合散点图预测对优势功能群生物量在某一环境因子的分布范围进行预测; 使用 CANOCO 5.0 软件对优势功 能群生物量作去趋势对应分析 (DCA), 排序轴长度为 0.8 , 故采用㝋余分析 (RDA).

\section{2 结果与分析}

\section{1 巴松错水体理化因子垂直分布}

现场测得巴松错枯水期和丰水期水体透明度均为 $0.85 \mathrm{~m}$. 巴松错枯水期 $R W C S$ 为 22.13 ,丰水期 $R W C S$ 为 53.26 , 表明巴松错水体稳定性强, 易发生分层. 枯水期和丰水期 $Z_{\text {eu }}$ 均为 $2.295 \mathrm{~m}$, 枯水期 $Z_{\text {mix }}$ 为 $23.81 \mathrm{~m}$, $Z_{\text {eu }} / Z_{\text {mix }}$ 为 0.10 , 比值较小, 混合深度较高, 光的可利用性较好; 丰水期 $Z_{\text {mix }}$ 为 $0.89 \mathrm{~m}, Z_{\mathrm{eu}} / Z_{\text {mix }}$ 为 2.58 , 比值较 大, 混合深度较低,光的可利用性较差.

巴松错水体理化因子垂直变化结果如图 2 所示. 枯水期水温在水深约 $30 \sim 60 \mathrm{~m}$ 处呈跃变趋势, 从 $8.9^{\circ} \mathrm{C}$ 降至 $5.93^{\circ} \mathrm{C}$, 水温变化梯度为 $0.1^{\circ} \mathrm{C} / \mathrm{m}$, 形成温跃层, 是传统 “混合层一温跃层一等温层” 单循环分层模式, 为 典型的 3 层结构型; 丰水期水温在水深约 $1 \sim 15 \mathrm{~m}$ 和 $30 \sim 60 \mathrm{~m}$ 处呈跃变趋势, 分别从 $14.73^{\circ} \mathrm{C}$ 降至 $9.1^{\circ} \mathrm{C}$ 、 $8.87^{\circ} \mathrm{C}$ 降至 $5.97^{\circ} \mathrm{C}$, 水温变化梯度分别为 0.4 和 $0.1^{\circ} \mathrm{C} / \mathrm{m}$, 形成两个温跃层, 这与传统的 “混合层一温跃层一

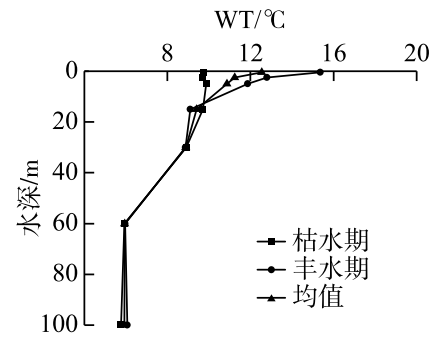

$\mathrm{TDS} /(\mathrm{mg} / \mathrm{L})$

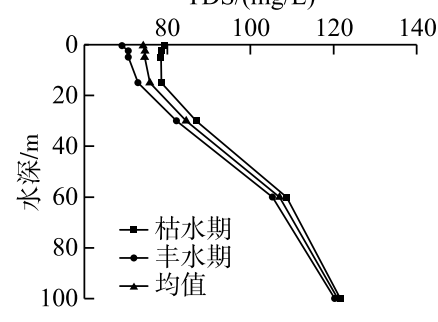

TUR/NTU

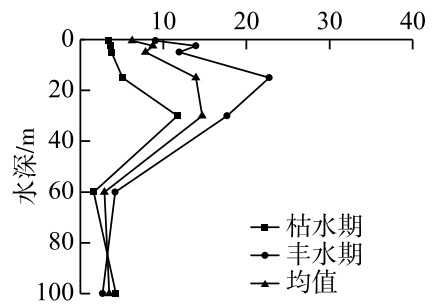

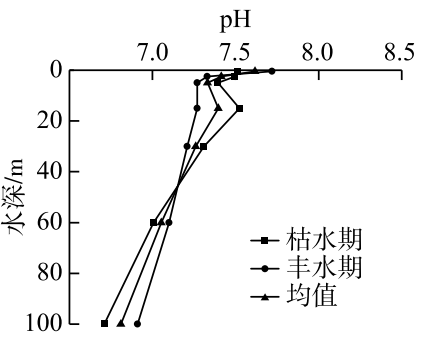

$\mathrm{Salt} /(\mathrm{mg} / \mathrm{L})$

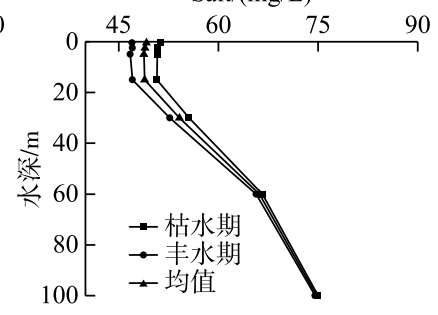

$\mathrm{TN} /(\mathrm{mg} / \mathrm{L})$

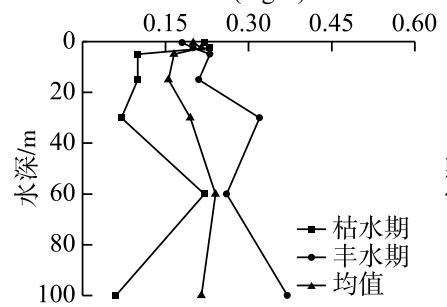

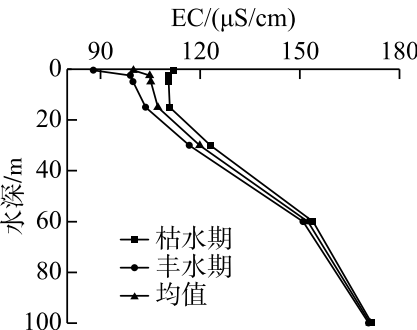

$\mathrm{DO} /(\mathrm{mg} / \mathrm{L})$

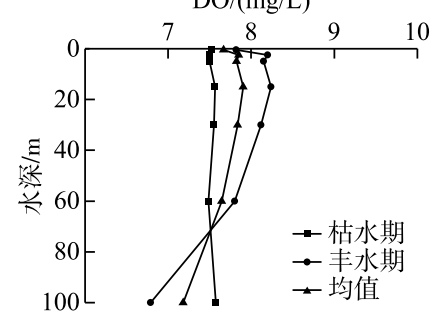

$\mathrm{NH}_{3}-\mathrm{N} /(\mathrm{mg} / \mathrm{L})$

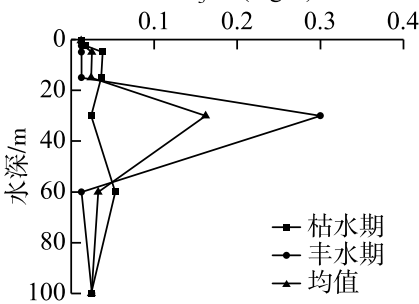

图 2 巴松错水体理化因子垂直变化

Fig.2 Vertical variation of physical and chemical factors in Lake Basomtso 
等温层” 单循环分层模式有所不同, 呈现 “混合层一温跃层一变温层一温跃层一等温层” 双循环分层模式, 为典 型的主温跃层上位型 ${ }^{[37]}$.

巴松错属于弱碱性湖泊, $\mathrm{pH}$ 范围为 6.71 7.72, 呈现从枯水期到丰水期逐步上升的趋势. EC 范围为 $87.93 \sim 171.63 \mu \mathrm{S} / \mathrm{cm}$, 平均值为 $122.98 \mu \mathrm{S} / \mathrm{cm}$, TDS 浓度变化范围为 $69.10 \sim 121.67 \mathrm{mg} / \mathrm{L}$, 平均值为 87.38 $\mathrm{mg} / \mathrm{L}$, 盐度变化范围为 $47.03 \sim 75.00 \mathrm{mg} / \mathrm{L}$, 平均值为 $55.86 \mathrm{mg} / \mathrm{L}, \mathrm{EC} 、 T D S$ 和盐度的变化趋于一致, 并呈现从 枯水期到丰水期逐步下降的趋势; DO 平均质量浓度是 $7.70 \mathrm{mg} / \mathrm{L}$, 最小值为 $6.79 \mathrm{mg} / \mathrm{L}$, 最大值为 $8.24 \mathrm{mg} /$ $\mathrm{L}$, 变化幅度较小; TUR、TN、 $\mathrm{NH}_{3}-\mathrm{N}$ 浓度呈波浪形分布特点, 其中 $\mathrm{NH}_{3}-\mathrm{N}$ 浓度在多数样点为下限值. 水体理 化因子在温跃层或温跃层附近变化显著,表明巴松错水体呈现出明显的垂直分布特征(图 2).

\section{2 巴松错浮游植物群落组成}

2.2.1 物种组成及群落结构 在巴松错 7 个全水深样点中共鉴定出浮游植物 242 种, 隶属于 7 门 纲 19 目 36 科 76 属, 其中硅藻门 25 属 120 种, 占 $49.59 \%$, 为该湖泊最主要的类群; 蓝藻门 14 属 57 种, 占 $23.55 \%$; 绿 藻门 26 属 51 种, 占 $21.07 \%$; 黄藻门 5 属 5 种, 占 $2.07 \%$; 裸藻门 3 属 4 种, 占 $1.65 \%$; 金藻门 1 属 3 种, 占 $1.24 \%$; 甲藻门 2 属 2 种, 占 $0.83 \%$. 巴松错枯水期和丰水期浮游植物种类均以硅藻门、蓝藻门和绿藻门为 主, 黄藻门、裸藻门和金藻门种类较少, 甲藻门种类只在丰水期出现. MRPP 结果表明, 浮游植物群落结构在 枯水期和丰水期具有显著的时空差异 $(P<0.05)$, 垂直样点浮游植物群落结构的空间异质性差异不显著 $(P>$ $0.05)$.

巴松错枯水期和丰水期浮游植物群落参数的垂直变化结果如图 3 所示. 枯水期, 巴松错各垂直样点浮 游植物物种数平均值为 36.57 , 范围为 $22 \sim 45$; 细胞丰度平均值为 $4.82 \times 10^{4} \mathrm{cells} / \mathrm{L}$, 范围为 $3.1 \times 10^{4} \sim 7.4 \times 10^{4}$ cells $/ \mathrm{L}$; 生物量平均值为 $0.12 \mathrm{mg} / \mathrm{L}$, 范围为 $0.08 \sim 0.19 \mathrm{mg} / \mathrm{L}$; Margalef 丰富度指数 $D_{\mathrm{m}}$ 在 $2.03 \sim 3.93$ 之间, 均 值为 3.3; Shannon-Wiener 多样性指数 $H^{\prime}$ 在 3.09 3.81 之间, 均值为 3.56; Simpson 优势度指数 $D_{\mathrm{s}}$ 的范围为 0.95 0.98, 均值为 0.97. 丰水期, 巴松错各垂直样点浮游植物物种数平均值为 67.71 , 范围为 $49 \sim 80$; 细胞丰 度平均值为 $28.9 \times 10^{4}$ cells $/ \mathrm{L}$, 范围为 $8.3 \times 10^{4} \sim 65 \times 10^{4}$ cells $/ \mathrm{L}$; 生物量平均值为 $0.83 \mathrm{mg} / \mathrm{L}$, 范围为 $0.20 \sim$
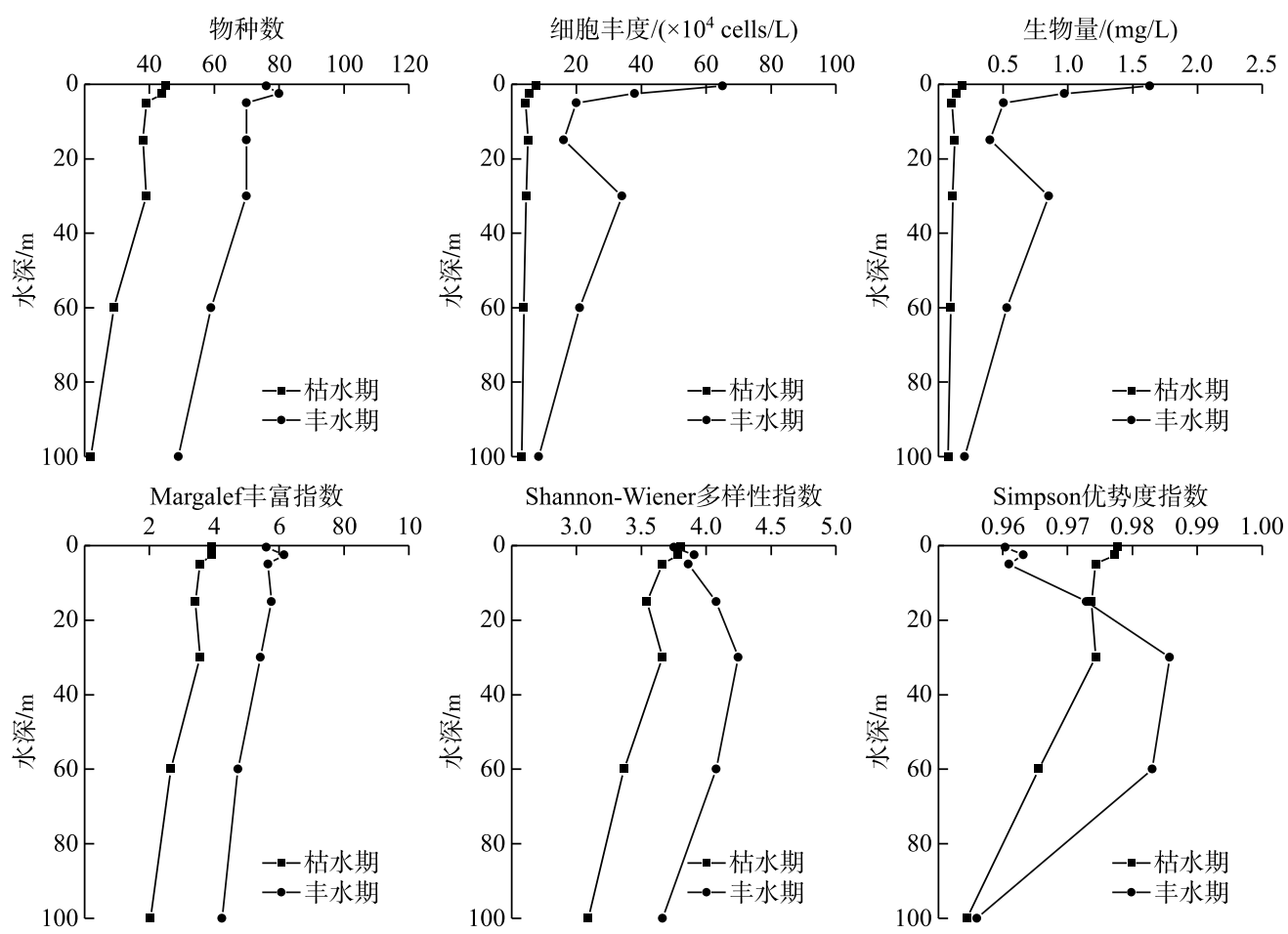

图 3 巴松错枯水期和丰水期浮游植物群落参数的垂直变化

Fig.3 Vertical variation of phytoplankton community parameters in Lake Basomtso during dry and wet seasons 
$1.63 \mathrm{mg} / \mathrm{L}$; Margalef 丰富度指数 $D_{\mathrm{m}}$ 在 4.24 6.15 之间,均值为 5.36 ; Shannon-Wiener 多样性指数 $H^{\prime}$ 在 3.66 4.25 之间, 均值为 3.94 ; Simpson 优势度指数 $D_{\mathrm{s}}$ 在 $0.96 \sim 0.99$ 之间, 均值为 0.97 . 由图 4 可见,在枯水期和丰 水期,巴松错浮游植物物种数、细胞丰度、生物量、Margalef 丰富度指数和 Shannon-Wiener 多样性指数差异显 著 $(P<0.05)$, Simpson 优势度指数差异不显著 $(P>0.05)$.
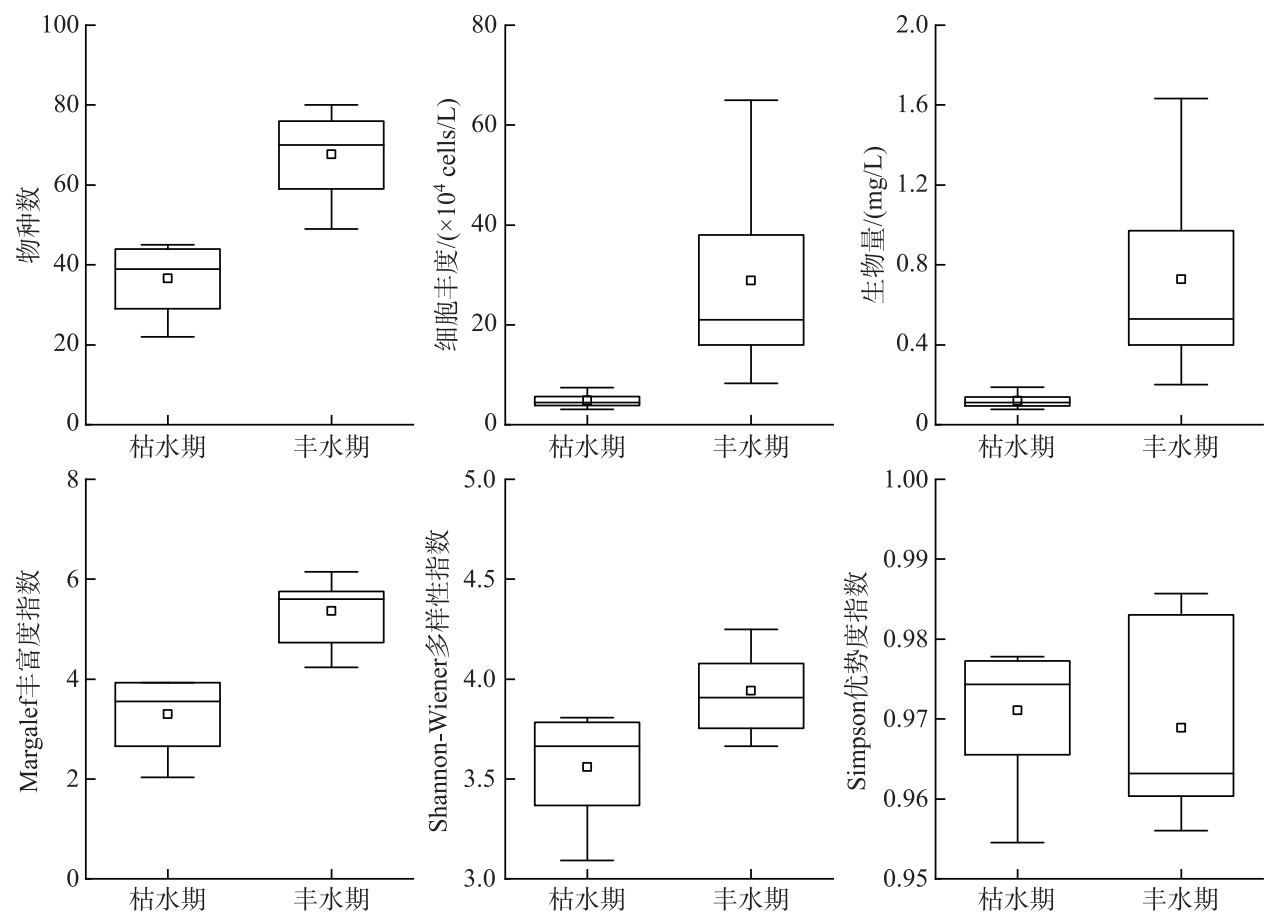

图 4 巴松错枯水期和丰水期浮游植物群落参数箱体图

Fig.4 Box-plots of phytoplankton community parameters in Lake Basomtso during dry and wet seasons

2.2.2 浮游植物功能群划分 根据功能群分类方法 ${ }^{[3-4]}$ 对巴松错浮游植物进行分类, 可分为 25 个功能群,包 括 $A 、 B 、 C 、 D 、 E 、 F 、 G 、 H 1 、 H 2 、 J 、 L_{M} 、 L_{0} 、 M 、 M P 、 N 、 P 、 S 1 、 S 2 、 T 、 W 1 、 W 2 、 X 1 、 X 2 、 X 3$ 和 $Y$, 其中枯水期 21 个功 能群分别为 $A 、 B 、 C 、 D 、 E 、 F 、 G 、 H 2 、 J 、 L_{0} 、 M 、 M P 、 N 、 P 、 S 1 、 S 2 、 T 、 W 1 、 X 1 、 X 2 、 X 3$, 丰水期 24 个功能群分别为 $A 、 B 、 C 、 D 、 E 、 F 、 H 1 、 H 2 、 J 、 L_{M} 、 L_{0} 、 M 、 M P 、 N 、 P 、 S 1 、 S 2 、 T 、 W 1 、 W 2 、 X 1 、 X 2 、 X 3$ 和 $Y, A 、 B 、 C 、 D 、 E 、 F 、 H 2 、 J 、 L_{0} 、$ $M 、 M P 、 N 、 P 、 S 1 、 S 2 、 T 、 W 1 、 X 1 、 X 2 、 X 3$ 是两个水情期共有的浮游功能群, 枯水期特有的浮游植物功能群为 $\mathrm{G}$, 丰水期特有的浮游植物功能群为 $\mathrm{H} 1 、 \mathrm{~L}_{\mathrm{M}} 、 \mathrm{~W} 2$ 和 $\mathrm{Y}$, 各功能群的代表性种 (属)、生境及其 C-R-S 生长策略 见表 1 , 其中 $C$ 型为竞争者 (competitors), $R$ 型为杂生者 (ruderals), $S$ 型为环境胁迫的耐受者 (stress-

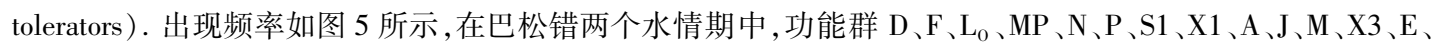
$\mathrm{S} 2 、 \mathrm{~T}$ 的出现频率均大于 $50 \%$, 出现频率较高, 为巴松错浮游植物常见的功能群; 功能群 $\mathrm{B} 、 \mathrm{C} 、 \mathrm{H} 1 、 \mathrm{~W} 1$ 的出现 频率在 20\% 50\% 之间, 仅在适宜的生境中出现; 功能群 $\mathrm{G} 、 \mathrm{H} 2 、 \mathrm{~L}_{\mathrm{M}} 、 \mathrm{~W} 2 、 \mathrm{X} 2 、 \mathrm{Y}$ 的出现频率在 $20 \%$ 以下, 出现 频率较低,为巴松错的偶见或罕见功能群.

将相对生物量至少在一个采样点大于 $10 \%$ 的浮游植物功能群定义为该采样点的优势功能群, 至少在一 个采样点大于 $50 \%$ 则该功能类群占据绝对优势 ${ }^{[7]}$. 根据巴松错 2 个水情期的浮游植物功能群相对生物量 (图 6) 可知, 巴松错枯水期以功能群 $D 、 L_{0} 、 M P 、 P$ 为优势功能群, 丰水期以功能群 $D 、 F 、 L_{0} 、 M P 、 N 、 P$ 为优势 功能群, 优势功能群 $\mathrm{D} 、 \mathrm{~L}_{0} 、 \mathrm{MP} 、 \mathrm{P}$ 在两个水情期稳定出现. 功能群 MP 在两个水情期的优势度均大于 $50 \%$, 成为巴松错浮游植物群落绝对优势群. 巴松错浮游植物功能群在枯水期至丰水期的空间更替明显, M1 样点 优势功能群从枯水期的 MP、D、 $\mathrm{L}_{0} 、 \mathrm{P}$ 转变为丰水期的 MP、 $D$; M 2 样点优势功能群从枯水期的 MP、 $P 、 L_{0} 、 D$ 
表 1 巴松错浮游植物功能群组成

Tab.1 Functional group composition of phytoplankton in Lake Basomtso

\begin{tabular}{|c|c|c|c|c|}
\hline 功能群 & 代表性种( 属) & 生长策略 & 生境 & $F$ 值 \\
\hline A & 胡克根枝藻 Rhizoclonium hookeri & $\mathrm{R}$ & 贫营养、洁净、深水 & 5 \\
\hline B & 星芒小环藻 Cyclotella steligera & $\mathrm{CR}$ & 中营养、中小型或大型浅水 & 3 \\
\hline $\mathrm{C}$ & 美丽星杆藻 Asterionella formosa & $\mathrm{R}$ & 富营养、中小型水体 & 5 \\
\hline $\mathrm{D}$ & 菱形藻属 Nitzschia, 针杆藻属 Synedra & $\mathrm{R}$ & 含有营养盐、浑浊 & 2 \\
\hline $\mathrm{E}$ & 雉囊藻属 Dinobryon & CS & 贫营养或异养型、小型、浅水 & 3 \\
\hline $\mathrm{F}$ & 纤细月牙藻 Selenastrum gracile & CS & 中富营养、清水、温跃层 & 5 \\
\hline G & 美丽团藻 Volvox aureus & CS & 富营养、净水 & 4 \\
\hline H1 & 多变鱼腥藻 Anabaena variabilis & CS & 富营养、分层、含氮低、浅水 & 0 \\
\hline $\mathrm{H} 2$ & 漂浮胶刺藻 Gloeotrichia natans & CS & 贫到中营养化、光照好、深水 & 3 \\
\hline $\mathrm{J}$ & 空星藻属 Coelastrum, 栅藻属 Scenedesmus & $\mathrm{CR}$ & 高营养、混合、浅水 & 1 \\
\hline $\mathrm{L}_{\mathrm{M}}$ & 角甲藻 Ceratium hirundinella, 不定微囊藻 Microcystis incerta & $\mathrm{S}$ & 富到超营养、中小型水体 & 0 \\
\hline $\mathrm{L}_{0}$ & 色球藻属 Chroococcus, 羽纹藻属 Pinnularia & $\mathrm{S}$ & 贫到富营养、中到大型水体 & 5 \\
\hline M & 微囊藻属 Microcystis & $\mathrm{S}$ & 富到超富营养、稳定、透明度低 & 0 \\
\hline MP & 桥弯藻属 Cymbella, 舟形藻属 Navicula & CR & 经常性搅动、浑浊、浅水 & 5 \\
\hline $\mathrm{N}$ & 棒形鼓藻 Gonatozygon monotaenium & $\mathrm{R}$ & 中营养、温跃层 & 5 \\
\hline $\mathrm{P}$ & 微小新月藻 Closterium parvulum & $\mathrm{R}$ & 中富营养、浅水、温跃层 & 5 \\
\hline S1 & 念珠藻属 Nostoc & $\mathrm{R}$ & 中富营养、混合浑浊、透明度低 & 0 \\
\hline S2 & 螺旋藻属 Spirulina & $\mathrm{R}$ & 温暖、浅水、高碱 & 2 \\
\hline $\mathrm{T}$ & 小刺角绿藻 Goniochloris brevipinosa & $\mathrm{R}$ & 具有光限制、表层持续混合水体 & 5 \\
\hline W1 & 裸藻属 Euglena & $\mathrm{R} / \mathrm{CS}$ & 有机污染、浅水 & 2 \\
\hline W2 & 粗刺四刺藻 Treubaria crassispina & $\mathrm{R} / \mathrm{CS}$ & 中营养、浅水 & 0 \\
\hline $\mathrm{X} 1$ & 纤维藻属 Ankistrodesmus & C & 超富营养、浅水 & 4 \\
\hline $\mathrm{X} 2$ & 具角翼膜藻 Pteromonas angulosa & $\mathrm{C}$ & 中富营养、浅水 & 3.5 \\
\hline $\mathrm{X} 3$ & 尖布纹藻 Gyrosigma acuminatum & $\mathrm{C}$ & 浅水、洁净、混合层 & 4 \\
\hline $\mathrm{Y}$ & 薄甲藻 Glenodinium pulvisculus & CRS & 静水环境、中到富营养 & 2 \\
\hline
\end{tabular}

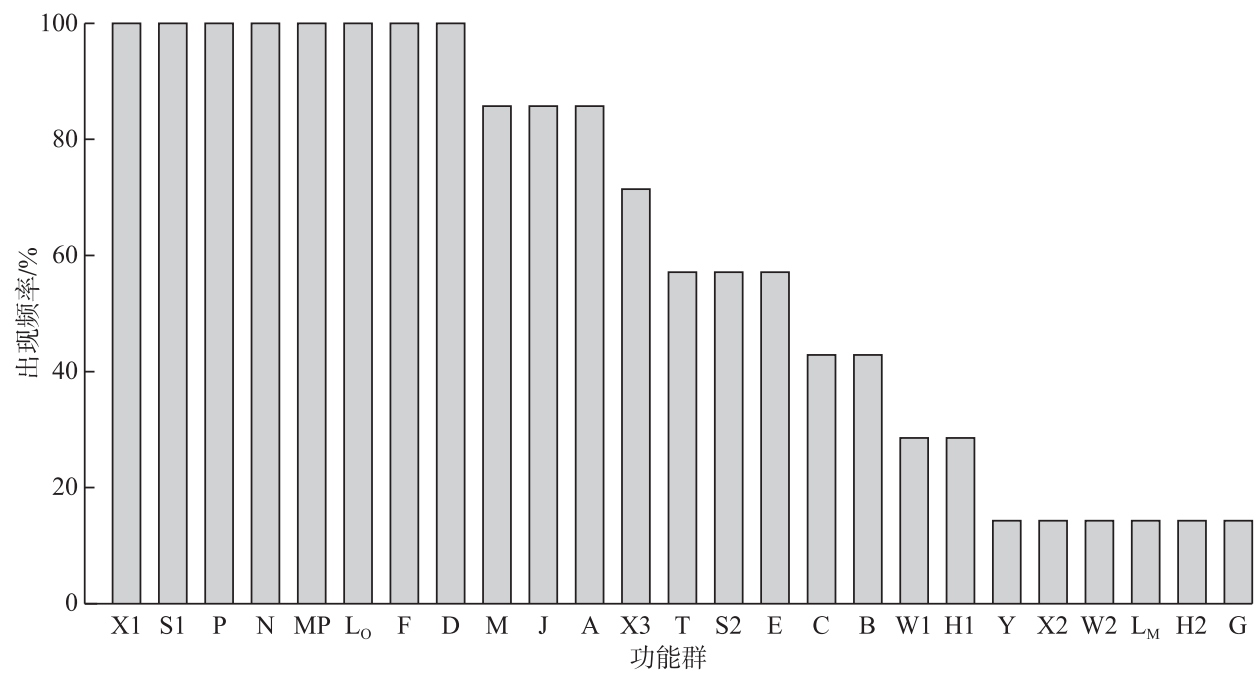

图 5 巴松错浮游植物功能群出现频率

Fig.5 Frequency of phytoplankton functional groups in Lake Basomtso 
转变为丰水期的 MP、 $P 、 D 、 N ; M 3$ 样点优势功能群从枯水期的 MP、 $P 、 L_{0}$ 转变为丰水期的 $M P 、 L_{0} 、 N 、 F ; M 4$ 样 点优势功能群从枯水期的 MP、 $P$ 转变为丰水期的 MP 、 $、 P ; M 5$ 样点优势功能群从枯水期的 MP $、 D 、 L_{0} 、 P$ 转 变为丰水期的 MP、P、D; M6 样点优势功能群从枯水期的 MP、D 转变为丰水期的 MP、P、D;M7 样点优势功能 群从枯水期的 MP、 $D 、 \mathrm{~L}_{0}$ 转变为丰水期的 MP.

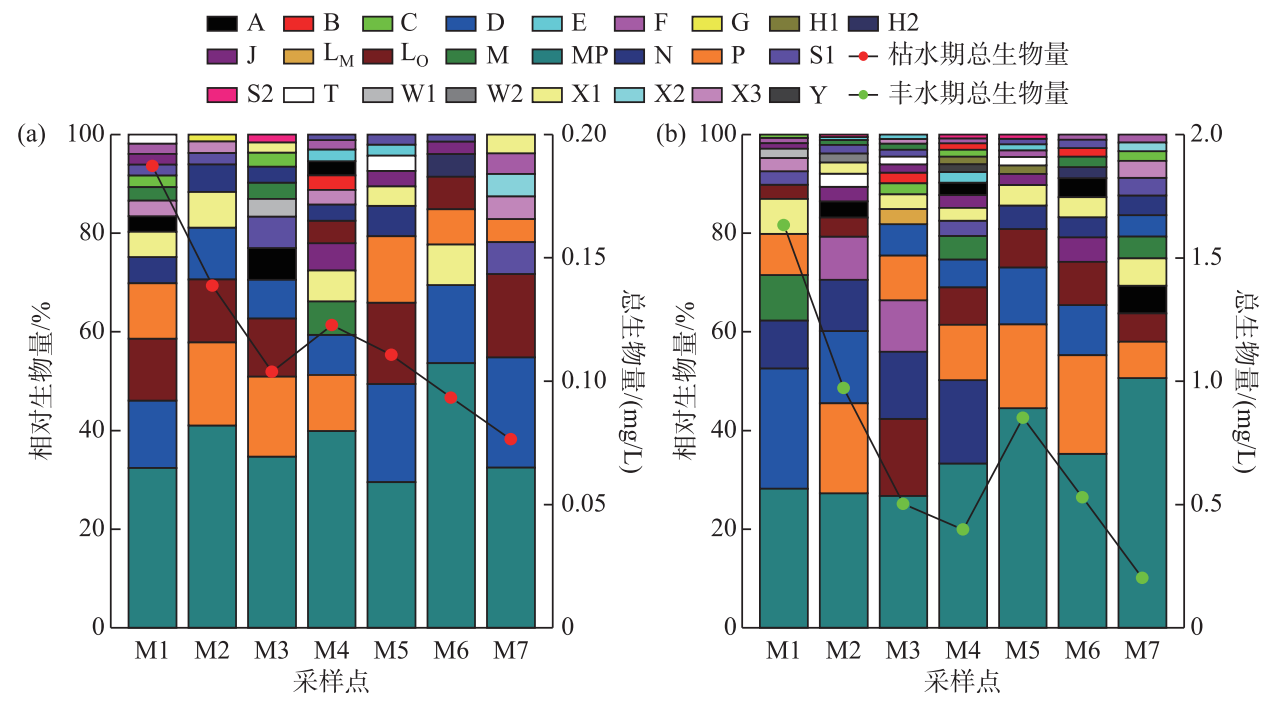

图 6 巴松错枯水期 (a) 和丰水期 (b) 浮游植物功能群相对生物量和总生物量

Fig.6 Relative biomass and total biomass among functional group of phytoplankton in Lake Basomtso during dry season (a) and wet season (b)

2.2.3 $Q$ 指数 基于浮游植物功能群的 $Q$ 指数对巴松错的水 质进行评价, 每个功能类群的代表值见表 1 , 枯水期和丰水期 $Q$ 指数见图 7. 枯水期, 巴松错浮游植物功能群的 $Q$ 指数平均 值为 4.12, 范围为 3.86 4.46; 丰水期, $Q$ 指数平均值为 4.13, 范围为 3.47 4.36. 根据 $Q$ 指数得出, 目前巴松错水质处于极 好状态, 其中巴松错 $Q$ 指数最大值出现在枯水期 M2 分层, 即 营养状态最低; 最小值出现在丰水期的 M1 分层, 即营养状态 最高.

\section{3 巴松错浮游植物与环境因子的关系}

2.3.1 优势功能群与环境因子的 Pearson 相关性分析 巴松错 各环境因子与优势功能群生物量之间的相关性分析结果显 示, 枯水期, 功能群 MP 生物量与 TN 浓度呈极显著正相关; 功 能群 $\mathrm{L}_{0}$ 生物量与 $\mathrm{NH}_{3}-\mathrm{N}$ 浓度呈极显著负相关; 功能群 $\mathrm{P}$ 生

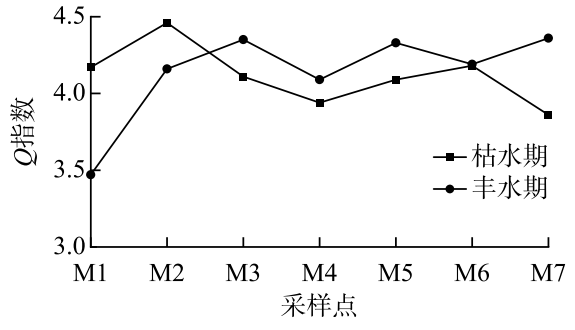

图 7 巴松错枯水期和丰水期浮游 植物功能群 $Q$ 指数点线图

Fig.7 Point plot of $Q$ index of phytoplankton functional group in Lake Basomtso during dry and wet seasons 物量与 $R W C S 、 \mathrm{pH}$ 、水温呈极显著正相关, 与水深、 $\mathrm{EC} 、 \mathrm{TDS}$ 、盐度呈极显著负相关. 丰水期, 功能群 $\mathrm{D}$ 生物量 与 $\mathrm{pH}$ 呈极显著正相关; 功能群 $\mathrm{N}$ 生物量与 RWCS 呈显著正相关, 与 $\mathrm{pH}$ 呈极显著正相关, 与 TDS、盐度、TN 呈显著负相关,与水深、EC 呈极显著负相关.

根据巴松错浮游植物优势功能群生物量与环境因子的相关性分析结果, 对与优势功能群生物量呈显著 和极显著相关的环境因子的分布情况进行预测 (图 8, 图 9). 由图 8 可见, 枯水期, 功能群 MP 集中出现在 TN 浓度为 $0.10 \sim 0.23 \mathrm{mg} / \mathrm{L}$ 的范围内; 功能群 $\mathrm{L}_{0}$ 集中出现在 $\mathrm{NH}_{3}-\mathrm{N}$ 浓度为 $0.012 \sim 0.036 \mathrm{mg} / \mathrm{L}$ 的范围内; 功能 群 $\mathrm{P}$ 集中出现在 $R W C S$ 为 $19.46 \sim 28.9 、 \mathrm{pH}$ 为 $7.31 \sim 7.52$ 、水温为 $8.9 \sim 9.86^{\circ} \mathrm{C}$ 、水深为 $0.5 \sim 30 \mathrm{~m}$ 、 $\mathrm{EC}$ 为 $110.53 \sim 123.1 \mu \mathrm{S} / \mathrm{cm}$ 、TDS 浓度为 78.43 86.93 mg/L、盐度为 $50.73 \sim 55.6 \mathrm{mg} / \mathrm{L}$ 的范围内. 由图 9 可见, 丰水 
期, 功能群 $\mathrm{D}$ 集中出现在 $\mathrm{pH}$ 为 7.21 7.72 范围内; 功能群 $\mathrm{N}$ 集中出现在 $R W C S$ 为 $18.08 \sim 109.88 、 \mathrm{pH}$ 为 $7.21 \sim$ 7.72 、水温为 $8.87 \sim 15.37^{\circ} \mathrm{C}$ 、TDS 浓度为 $69.1 \sim 82.2 \mathrm{mg} / \mathrm{L}$ 、盐度为 $46.77 \sim 52.7 \mathrm{mg} / \mathrm{L}$ 、 $\mathrm{TN}$ 浓度为 $0.18 \sim 0.26$ $\mathrm{mg} / \mathrm{L}$ 、水深为 $0.5 \sim 30 \mathrm{~m} 、 \mathrm{EC}$ 为 $87.93 \sim 116.77 \mu \mathrm{S} / \mathrm{cm}$ 范围内.
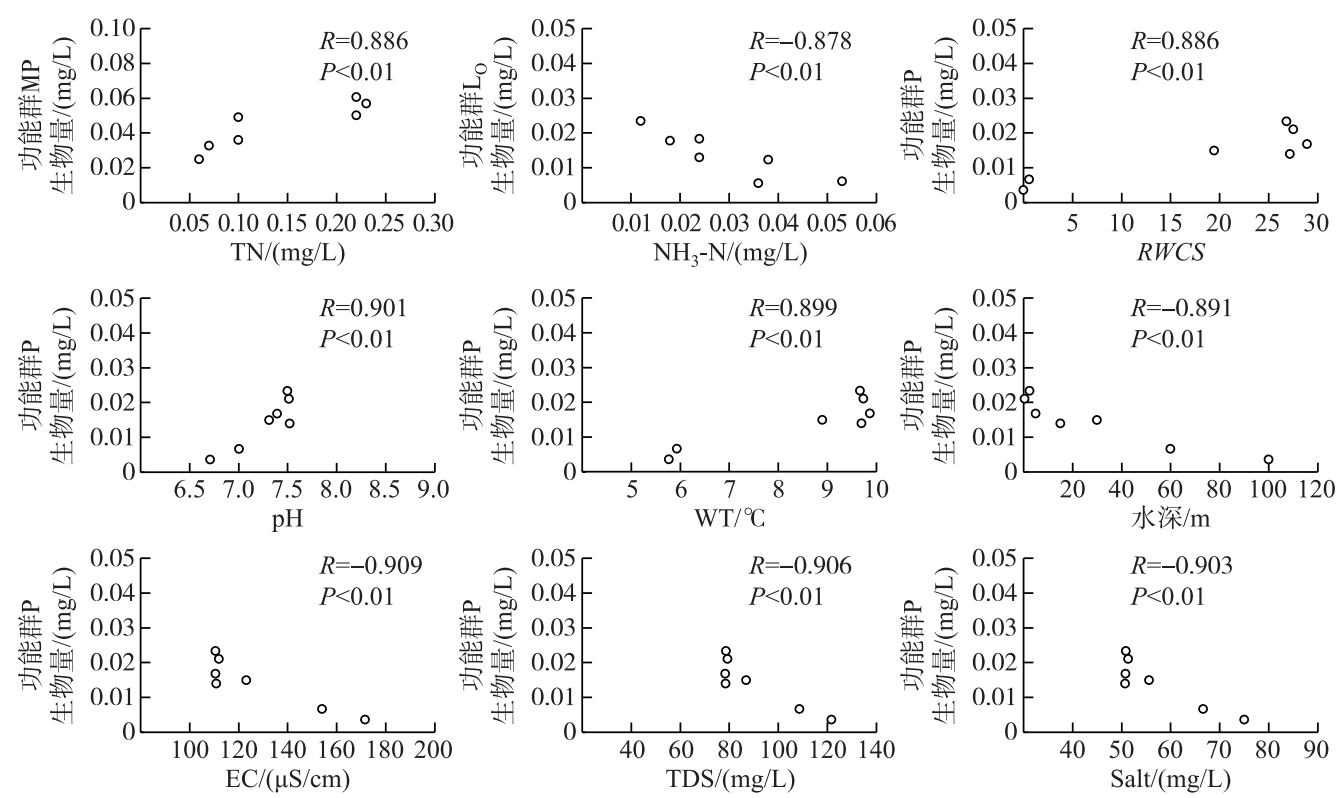

图 8 巴松错枯水期浮游植物优势功能群与部分水环境因子的相关性

Fig.8 Concordance correlations between several phytoplankton dominant functional groups and environment factors in Lake Basomtso during the dry season
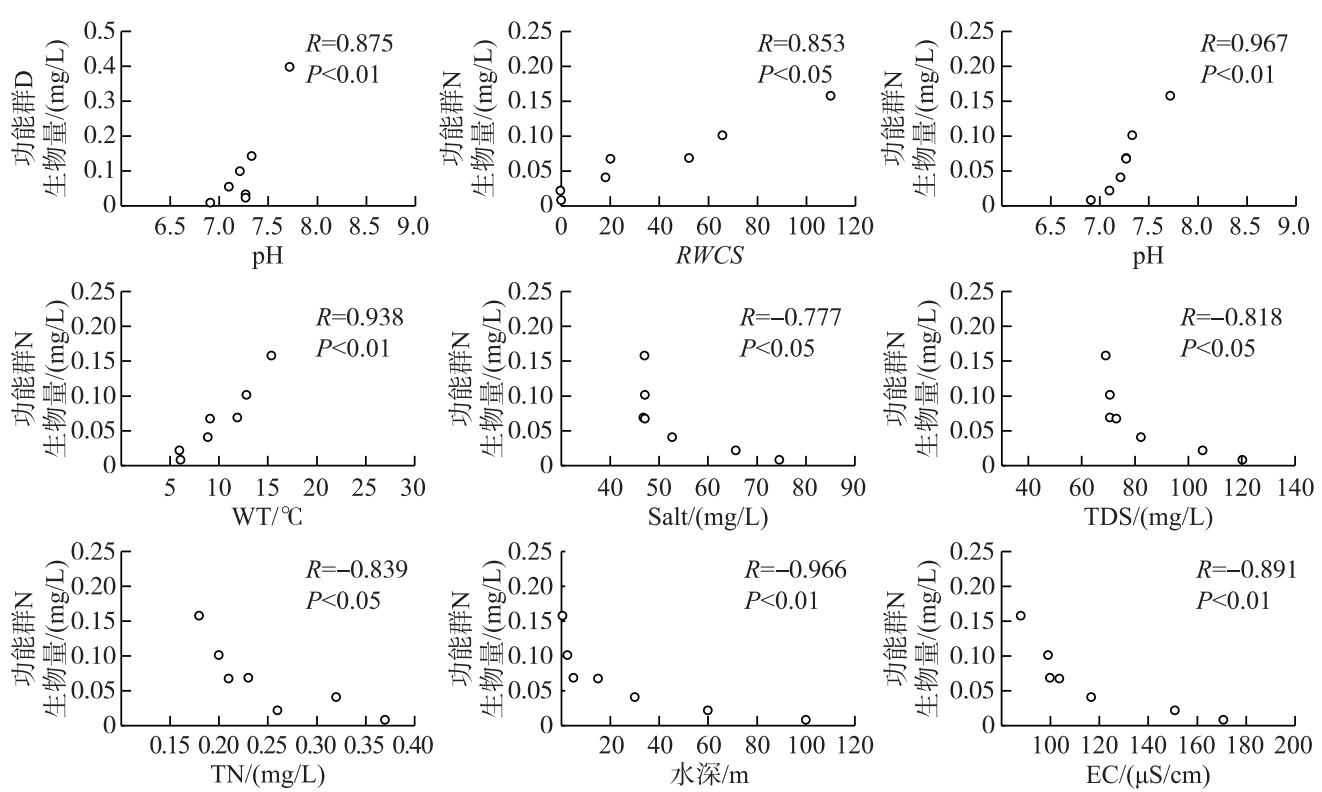

图 9 巴松错丰水期浮游植物优势功能群与部分水环境因子的相关性

Fig.9 Concordance correlations between several phytoplankton dominant functional groups and environment factors in Lake Basomtso during the wet season 
2.3.2 优势功能群与环境因子的冗余分析 为了探究环境因子对巴松错浮游植物群落分布的影响, 首先选取 巴松错枯水期的优势功能群生物量进行 DCA 分析, 结果排序轴长度小于 3 , 表明优势功能群的分布可使用 线性模型, 共有 11 个环境因子 $R W C S$ 、水深、 $\mathrm{pH} 、 \mathrm{EC} 、 \mathrm{TDS}$ 、盐度、水温、DO、TUR、TN 和 $\mathrm{NH}_{3}-\mathrm{N}$ 进行 RDA 分析. 应用蒙特卡拟合方法对环境因子进行显著性检验. 通过篎选, TN $(P=0.022, F=4.7) 、 \mathrm{NH}_{3}-\mathrm{N}(P=0.046, F=$ 2.7 和 $\mathrm{pH}(P=0.042, F=3.4)$ 是显著解释性变量, 对群落变异的解释率分别为 $48.4 \% 、 21.0 \%$ 和 $16.3 \%$, 是影响 巴松错枯水期浮游植物群落变异的主要环境因子, 影响并不显著的环境因子用虚线表示, 结果如图 10 所示. 从图 10 可以看出,第 1 排序轴与第 3 排序轴对优势功能群生物量方差的解释率分别为 $65.81 \%$ 和 $22.54 \%$, 优势功能群生物量与环境因子的相关性分别为 0.9825 和 0.9488 , 前两轴累计方差为 $88.35 \%$, 表明前两轴能 较好地反映优势功能群生物量与环境因子的关系, 且主要是由第 1 排序轴决定; 第 1 排序轴与 $\mathrm{NH}_{3}-\mathrm{N}$ 浓度 呈正相关, 与 $\mathrm{TN}$ 浓度和 $\mathrm{pH}$ 呈负相关; 第 2 排序轴与 $\mathrm{pH}$ 呈正相关, 与 $\mathrm{TN}$ 和 $\mathrm{NH}_{3}-\mathrm{N}$ 浓度呈负相关. 功能群 $M P 、 L_{0} 、 D$ 和 $\mathrm{P}$ 与 $\mathrm{pH} 、 \mathrm{TN}$ 浓度呈显著正相关, 与 $\mathrm{NH}_{3}-\mathrm{N}$ 浓度呈显著负相关.

将巴松错丰水期的优势功能群生物量进行 DCA 分析, 结果排序轴长度小于 3 , 表明优势功能群的分布 可使用线性模型, 对同样的 11 个环境因子应用蒙特卡拟合方法对环境因子进行显著性检验. 通过䇻选, 仅 $\mathrm{pH}(P=0.02, F=8.0)$ 是显著解释性变量, 对群落变异的解释率为 $61.5 \%$, 是影响巴松错丰水期浮游植物群落 变异的主要环境因子, 影响并不显著的环境因子同样用虚线表示, 结果如图 10 所示. 结果显示, 第 1 排序轴 与第 2 排序轴对优势功能群生物量方差的解释率分别为 $82.53 \%$ 和 $12.13 \%$, 优势功能群生物量与环境因子 的相关性分别为 0.9926 和 0.9488 , 前两轴累计方差为 $99.67 \%$, 表明前两轴能较好地反映优势功能群生物量 与环境因子的关系, 且主要是由第 1 排序轴决定; 第 1 排序轴与 $\mathrm{pH}$ 呈正相关; 第 2 排序轴与 $\mathrm{pH}$ 呈负相关. 功能群 $M P 、 L_{0} 、 F 、 D 、 N$ 和 $P$ 与 $p H$ 呈显著正相关.
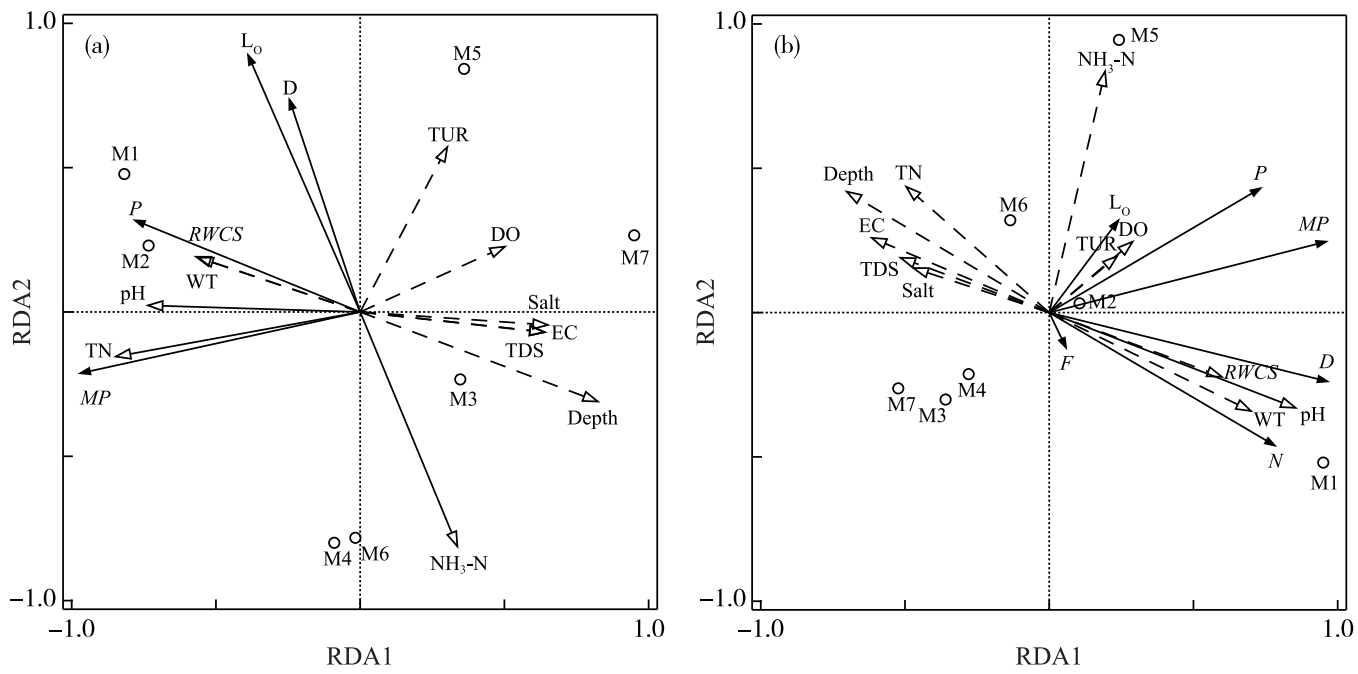

图 10 巴松错枯水期 (a) 和丰水期 (b) 浮游植物功能群与环境因子的 RDA 分析

Fig.10 RDA analysis of phytoplankton dominant function groups and environment factors in

Lake Basomtso during dry season (a) and wet season (b)

\section{3 讨论}

\section{1 巴松错水质垂直分布特征}

大型深水湖库由于夏、秋季太阳辐射强, 水体分层温差大、持续时间长, 对水体水质分布和浮游植物群 落影响较大 ${ }^{[38]}$. 通过对巴松错环境因子的两个水情期的分层研究表明, 该湖泊在枯水期和丰水期均出现水

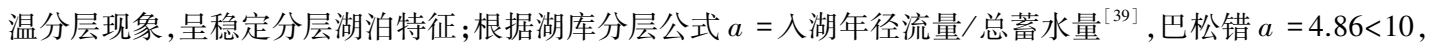
水温分布呈稳定分层型, 该结果与实际研究结论一致. 
本研究显示, 巴松错水体透明度较低, 其原因可能主要为夏秋季水温较高、日照时间长, 从而导致浮游 植物大量繁殖, 悬浮物质较多, 湖水较浑 ${ }^{[40]}$. 巴松错水体相对稳定性从枯水期到丰水期呈升高趋势, 而混合 层的高度从枯水期到丰水期呈逐渐降低趋势, 主要表现为巴松错水体在枯水期和丰水期均出现明显的水温 分层现象, 枯水期在 30 60 m 处形成温跃层, 丰水期在 1 15 m 和 30 60 m 处产生双温跃层. 枯水期, 水温 从表层至水深 $30 \mathrm{~m}$ 处变化不大, 由于逆温的影响, 混合层较高, 湖底水体受紊流扩散和热量传递的作用很 小, 恒温层与湖泊混合层之间形成了垂向厚度约 $30 \mathrm{~m}$ 的温跃层. 丰水期,巴松错水体形成双温跃层结构, 是 高温温跃层压迫湖底等温层但难以对其进行充分扰动的结果, 这与李嘉等 ${ }^{[41]}$ 对雅聋江卡拉水库和张士杰 等 ${ }^{[42]}$ 对二滩水库的研究结果基本一致, 主要由于太阳辐射较强、气温较高, 湖泊表面水体快速升温, 在湖泊 表层以下出现第一个约 $14 \mathrm{~m}$ 厚度的温跃层; 湖泊人流和出流产生的纵向水流在温度异重流的作用下, 人流 沿温跃层与人流温度接近的水层流动, 而且垂向水体受紊流的影响比较强烈, 从而在温跃层以下出现一个 约 $15 \mathrm{~m}$ 厚度的变温层; $60 \mathrm{~m}$ 以下为恒温层, 湖底水体受紊流扩散和热量传递的作用很小, 因而与湖泊变温 层之间形成第 2 个垂向厚度约 $30 \mathrm{~m}$ 的温跃层. 而水体温跃层的出现, 上下水层的物质和能量交换受到阻 碍, 导致下层水体的 EC、TDS、盐度显著高于上层水体, 卢金锁等 ${ }^{[43]}$ 对西安黑河水库理化因子分布特征的研 究也表明在水温分层情况下, 理化因子在不同水层表现出明显的垂直变化特征, 主要是由于随着水深的增 加, 光合作用减弱, 在垂向上易于产生生物分层 (表层多为自养型生物, 底层多为异养型生物), 而异养型生 物在释放和分解有机物的过程中, 代谢排放的产物 (硝酸铵、碳酸氢根等) 以及碎屑, 致使 $\mathrm{pH}$ 降低, 水体呈弱 酸性,从而导致浊度、盐度、 $\mathrm{NH}_{3}-\mathrm{N} 、 \mathrm{TDS}$ 和 $\mathrm{EC}$ 呈逐渐上升趋势 ${ }^{[44]}$.

通常湖泊水温分层效应对水体 DO 浓度有明显的影响, 表层水体由于复氧作用和光合作用 DO 浓度通 常较高; 而底层水体因不能与 DO 浓度较高的表层水混合, DO 浓度较低, 加之底泥有机物分解不断消耗水中 的 DO, 常出现缺氧状态甚至厌氧状态 ${ }^{[45]}$, 但在枯水期和丰水期, 巴松错水体垂向上并未出现较大差异, 底部 $100 \mathrm{~m}$ 处水体 DO 浓度分别处于 7.49 和 $6.49 \mathrm{mg} / \mathrm{L}$ 的较饱和状态, DO 浓度差值分别为 0.08 和 $1.45 \mathrm{mg} / \mathrm{L}$, 主 要原因是随着水深增加, 微生物活性降低, 耗氧量减少, 巴松错水体含氧量呈现缓慢下降趋势, 特别是枯水 期湖水相对静止, 降低的趋势更加不明显.

\section{2 巴松错浮游植物群落结构及功能群垂直分布特征}

MRPP 结果显示, 巴松错浮游植物群落结构存在明显的时空差异, 枯水期和丰水期均以硅藻门、蓝藻门 和绿藻门为主, 物种组成表现为硅藻一蓝藻一绿藻型, 这与孙文秀等 ${ }^{[46]}$ 对东湖水库和田泽斌等 ${ }^{[47]}$ 对三峡水 库香溪河库湾的研究结果基本一致, 表明巴松错浮游植物种群组成具有一般湖库的普遍性特征. 巴松错浮 游植物物种数、细胞丰度、生物量、Margalef 丰富度指数和 Shannon-Wiener 多样性指数的时空差异显著, 这与 刘霞等 ${ }^{[48]}$ 对密云水库和李秋华等 ${ }^{[49]}$ 对大镜山水库的研究结果基本一致. 而巴松错枯水期和丰水期浮游植 物主要分布在湖体的表层和温跃层, 细胞丰度、生物量和多样性最大值出现在表层, 深层显著降低, 表明巴 松错浮游植物群落结构在水体垂直方向上具有一定规律性, 与水体热分层现象密切相关, 这与牛远等 ${ }^{\left[{ }^{[00}\right.}$ 对 抚仙湖和曾明正等 ${ }^{[51]}$ 对周村水库的研究结果基本一致,温跃层的存在致使上下水层的物理化学性质差异明 显, 形成了不同的生境, 生境异质性是影响巴松错浮游植物群落的重要因素, 因此对巴松错浮游植物群落结 构的探讨和分析应建立在水温分层研究的基础上.

巴松错共划分出 25 个浮游植物功能群, 优势功能群从枯水期的 MP、 $D 、 L_{0} 、 P$ 转变为丰水期的 $D 、 F 、 L_{0} 、$ $M P 、 N 、 P$, 其中 MP 为两个水情期的绝对优势功能群, $M P 、 D 、 L_{0} 、 P$ 均为两个水情期共有优势功能群, 丰水期 和枯水期相比多了 $\mathrm{F}$ 和 $\mathrm{N}$ 功能群, 表现出明显的时空垂直分布特征, 这与杨丽等 ${ }^{[6]}$ 对淀山湖和陈楠等 ${ }^{[52]}$ 对 泰湖的研究结果基本一致, 这主要的原因是巴松错为 $5 \mathrm{~A}$ 级旅游景区, 枯水期旅游活动为淡季, 人流量较少, 船舶活动量小, 雨水较少, 人湖流量较小, 营养物质贯乏, 混合层较高; 而进人丰水期, 旅游活动转为旺季, 人 流量增大, 船舶活动量大, 雨水充足, 通过入湖河流带来丰富的营养物质, 加上水温升高, 形成了双温跃层, 混合层较低, 适宜功能群 $\mathrm{F} 、 \mathrm{~N}$ 等喜温跃层的浮游植物生长, 从而导致两个水情期功能群的垂直分布变化.

基于浮游植物功能群的 $Q$ 指数对巴松错的水质进行评价发现,枯水期和丰水期巴松错水质均处于极好 状态. 从浮游植物生境上看, 巴松错浮游植物优势功能群中, MP 功能群指示经常性扰动、浑浊水体, Lo 功能 群指示贫到富营养水体, $\mathrm{N}$ 功能群指示中营养型水体, P、F 功能群指示中到富营养型水体, D 功能群指示较 
高的营养盐浓度 ${ }^{[4]}$. 因此, 从功能群上推测, 巴松错水体处于营养相对较高的状态, 这与 $Q$ 指数判定巴松错 水质处于极好状态的结果不一致, 可能原因是巴松错周围旅游活动如船舶的频繁活动和人为干扰等, 加上 雨水淋溶和下游筑坝形成水库的影响 ${ }^{[13]}$, 水体流速大幅降低, 内源有机质在湖内逐渐累积, 导致营养盐相对 较高, 这为浮游植物生长提供了丰富的营养物质.

\section{3 巴松错浮游植物与环境因子的关系}

环境因子是浮游植物群落分布的主要影响因素, 水体透明度、浊度、水温、盐度、DO 和 $\mathrm{pH}$ 等环境因子都 对浮游植物群落分布产生影响, 并且特定功能群对生境的选择与适应性也不同 ${ }^{[33]}$. 本研究中, 巴松错浮游 植物优势功能群生物量与水环境因子的相关性分析表明, 枯水期浮游植物优势功能群中, 仅功能群 MP 生物 量与 $\mathrm{TN}$ 浓度呈极显著正相关, 功能群 $\mathrm{L}_{0}$ 生物量与 $\mathrm{NH}_{3}-\mathrm{N}$ 浓度呈极显著负相关, 说明巴松错浮游植物枯水 期优势功能群对 $\mathrm{TN}$ 及 $\mathrm{NH}_{3}-\mathrm{N}$ 浓度变化有显著影响. 功能群 MP 能适应经常性扰动、浑浊水体, 而 $\mathrm{L}_{0}$ 功能群 的适应生境广泛, 也常分布于湖库水体, 原因是这两种功能群的表面积较大且有较厚的硅壳, 能适应频繁扰 动的水体 ${ }^{[4]}$, 本研究结果与其一致, 因此还需要进一步研究 $\mathrm{TN}$ 及 $\mathrm{NH}_{3}-\mathrm{N}$ 浓度对湖库浮游植物的影响. 功能 群 $\mathrm{P}$ 生物量与绝大多数环境因子呈显著相关, 可能的原因是功能群 $\mathrm{P}$ 适应生境为栖息在中富营养的温跃 层, 对水体分层敏感, 表明功能群 $\mathrm{P}$ 对理化因子适应性更广. 丰水期, 仅功能群 $\mathrm{D}$ 生物量与 $\mathrm{pH}$ 呈极显著正 相关, 主要原因是硅藻门受 $\mathrm{pH}$ 影响更为显著 ${ }^{[54]}$, 而功能群 $\mathrm{D}$ 的主要代表中主要为硅藻门, 因此可以得知功 能群 $\mathrm{D}$ 受 $\mathrm{pH}$ 的影响较大. $\mathrm{N}$ 功能群生物量与绝大多数环境因子呈显著相关, 可能的原因是功能群 $\mathrm{N}$ 适应 的生境与功能群 $\mathrm{P}$ 相似, 对水体分层敏感, 和功能群 $\mathrm{P}$ 一样表现出对理化因子广适性. 对与优势功能群的生 物量呈显著相关和极显著相关的环境因子的分布范围进行预测, 结果表明, 这些环境因子的分布范围均接 近于湖心 $(\mathrm{M})$ 水环境因子的平均值, 这可能是浮游植物群落与环境因子相互作用形成的动态适应机制, 这 与闵文武等 ${ }^{[55]}$ 对渭河流域的研究结果基本一致.

巴松错浮游植物优势功能群生物量与环境因子的 RDA 分析表明: 枯水期, $\mathrm{TN} 、 \mathrm{NH}_{3}-\mathrm{N}$ 浓度和 $\mathrm{pH}$ 是影响 巴松错浮游植物群落变异的主要环境因子; 丰水期, $\mathrm{pH}$ 是影响巴松错浮游植物群落变异的主要环境因子; 因此, 不同水情期浮游植物功能群垂直分布特征受环境因子影响差异较明显, 整体上, $\mathrm{pH} 、 \mathrm{TN}$ 和 $\mathrm{NH}_{3}-\mathrm{N}$ 浓度 是影响浮游植物功能群分布格局的主要环境因素, 这与葛优等 ${ }^{[2]}$ 对阳澄西湖和冯喻等 ${ }^{[56]}$ 对高州水库的研究 结果基本一致. 而通常不同的水生态系统会造成不同的生物以及非生物过程, 影响浮游植物生物量分布以 及优势功能群组成的环境因子也存在较大的差别 ${ }^{[57]}$. 夏芗霏等 ${ }^{[58]}$ 研究发现水温、透明度、BOD $、$ 、TN、TP 和 DO 浓度是影响太湖浮游植物功能群分布的主要因素; 钱奎梅等 ${ }^{[5]}$ 研究发现水位变化、透明度、悬浮物、水 温、亚硝态氮及电导率是鄱阳湖浮游植物功能群分布格局的主要环境影响因子. $\mathrm{TN}$ 和 $\mathrm{NH}_{3}-\mathrm{N}$ 浓度是浮游植 物生长代谢不可或缺的营养盐, 影响浮游植物的生长和群落结构的演替 ${ }^{[6]}$. 本研究中, $\mathrm{TN}$ 和 $\mathrm{NH}_{3}-\mathrm{N}$ 浓度在 枯水期显著高于丰水期, 且温跃层差异更显著, 这是因为枯水期流量较小, 仅为 $13.4 \mathrm{~m}^{3} / \mathrm{s}$, 水力滞留时间长, 导致巴松错 $\mathrm{TN}$ 和 $\mathrm{NH}_{3}-\mathrm{N}$ 浓度升高. 研究表明, 藻类适宜在偏碱性的水体中生长, 这与本研究结果一致 ${ }^{[59]}$, 这主要是因为湖泊中水深的增加会使水体与大气接触的表面积相对减少, DO 浓度降低,下层水体在产酸细 菌的影响下, $\mathrm{pH}$ 值降低, 这不仅仅改变了大多数浮游植物适应的生存环境, 降低了物种的耐受性, 限制了大 多数浮游植物的生存与繁衍, 利于对 $\mathrm{pH}$ 值变化敏感的种类的生长. 由此可见, 浮游植物垂直分布特征是不 同分层浮游植物和多种环境因子共同作用的结果.

\section{4 参考文献}

[ 1 ] Hu R, Lan YQ, Xiao LJ et al. The concepts, classification and application of freshwater phytoplankton functional groups. $J$ Lake Sci, 2015, 27(1): 11-23. DOI: 10.18307/2015.0102. [胡韧, 蓝于倩, 肖利娟等. 淡水浮游植物功能群的概 念、划分方法和应用. 湖泊科学, 2015, 27(1): 11-23.]

[2] Ge Y, Zhou YF, Wang CH et al. Succession patterns of phytoplankton functional groups in western area of Yangcheng Lake and their relationship with environmental factors. China Environmental Science, 2019, 39(7) : 3027-3039. [ 葛优, 周彦锋, 王晨赫等. 阳澄西湖浮游藻类功能群演替特征及其与环境因子的关系. 中国环境科学, 2019, 39(7): 3027-3039.]

[ 3 ] Reynolds CS, Huszar V, Kruk C et al. Towards a functional classification of the freshwater phytoplankton. Journal of 
Plankton Research, 2002, 24(5) : 417-428. DOI: 10.1093/plankt/24.5.417.

[ 4 ] Padisák J, Crossetti LO, Naselli-Flores L. Use and misuse in the application of the phytoplankton functional classification: A critical review with updates. Hydrobiologia, 2009, 621 (1) : 1-19. DOI: 10.1007/s10750-008-9645-0.

[ 5 ] Qian KM, Liu BG, Chen YW. Long term dynamics of phytoplankton functional groups in Lake Poyang during 2009-2016. $J$ Lake Sci, 2019, 31(4) : 1035-1044. DOI: 10.18307/2019.0402. [钱奎梅, 刘宝贵, 陈宇炜. 鄱阳湖浮游植物功能 群的长期变化特征(2009-2016 年). 湖泊科学, 2019, 31(4) : 1035-1044.]

[ 6 ] Yang L, Zhang W, Shang GX et al. Succession characteristics of phytoplankton functional groups and their relationships with environmental factors in Dianshan Lake, Shanghai. Environmental Science, 2018, 39(7) : 3158-3167. DOI: 10. 13227/j.hjkx.201710030. [杨丽, 张玮, 尚光霞等. 淀山湖浮游植物功能群演替特征及其与环境因子的关系. 环境 科学, 2018, 39(7): 3158-3167.]

[ 7 ] Huang GJ, Li QH, Chen C et al. Phytoplankton functional groups and their spatial and temporal distribution characteristics in Hongfeng Reservoir, Guizhou Province. Acta Ecologica Sinica, 2015, 35(17) : 5573-5584. [黄国佳, 李秋华, 陈椽 等. 贵州高原红枫湖水库浮游植物功能分组及其时空分布特征. 生态学报, 2015, 35(17): 5573-5584.]

[ 8 ] Zhang GQ, Luo W, Chen WF et al. A robust but variable lake expansion on the Tibetan Plateau. Science Bulletin, 2019, 64(18) : 1306-1309. DOI: 10.1016/j.scib.2019.07.018.

[ 9 ] Chen ZM. Approaches to the changes of ecological environment of lakes in Xizang based on the upheaval of the Qinghai-Xizang Plateau. Oceanologia et Limnologia Sinica, 1981, (5) : 402-411. [陈志明. 从青藏高原隆起探讨西藏湖泊生态 环境的变迁. 海洋与湖沼, 1981, (5) : 402-411.]

[10] Zhang JY, Liu JF, Jin JL et al. Evolution and trend of water resources in Qinghai-Tibet Plateau. Bulletin of Chinese Academy of Sciences, 2019, 34(11): 1264-1273. [张建云, 刘九夫, 金君良等. 青藏高原水资源演变与趋势分析. 中国科 学院院刊, 2019, 34(11): 1264-1273.]

[11] Yan LX, Sun MP, Yao XJ et al. Lake water in the Tibet Plateau: Quality change and current status evaluation. Acta Scientiae Circumstantiae, 2018, 38(3) : 900-910. [间露霞, 孙美平, 姚晓军等. 青藏高原湖泊水质变化及现状评价. 环境 科学学报, 2018, 38(3): 900-910.]

[12] Jin CF, Li SJ, Chen W et al. Climate changes on the Tibetan plateau inferred from organic geochemistry records in lake sediments-A case of Lake Zigetang Co. Bulletin of Mineralogy, Petrology and Geochemistry, 2016, 35(4): 625-633, 607. DOI: 10.3969/j.iss.1007-2802.2016.04.003. [金传芳, 李世杰, 陈炜等. 青藏高原气候演变的湖相沉积有机地 球化学记录——以兹格塘错为例. 矿物岩石地球化学通报, 2016, 35(4):625-633, 607.]

[13] Gong YC, Feng WS, Yu YH et al. Characteristics of zooplankton community structure in Niyang River Basin of Tibet. Journal of Hydroecology, 2012, 33(6): 35-43. [龚迎春, 冯伟松, 余育和等. 西藏尼洋河流域浮游动物群落结构研 究. 水生态学杂志, 2012, 33(6) : 35-43.]

[14] Fang MY, Dong F, He JQ. Study on resources ofmacrofungi In Basomtso National Forest Park. Edible Fungi of China, 2018, 37(2) : 7-10. [方梦洋, 董帆, 何建清. 西藏巴松措国家森林公园大型真菌物种多样性分析. 中国食用菌, 2018, 37(2): 7-10.]

[15] An RZ, Pan CM, Liu Y et al. Study on the distribution pattern and coexistence mechanism of dominant summering phytoplankton population in the Basomtso. Plateau Science Research, 2020, 4(2): 27-36. [安瑞志, 潘成梅, 刘洋等. 巴松措 (湖) 夏季浮游植物优势种群分布格局与共存机制研究. 高原科学研究, 2020, 4(2): 27-36.]

[16] The Qinghai-Tibet Plateau Comprehensive Scientific Expedition of Chinese Academy of Sciences ed. Tibet water conservancy. Beijing: Science Press, 1981. [中国科学院青藏高原综合科学考察队. 西藏水利. 北京: 科学出版社, 1981.]

[17] Li ZX, Zhu HR, Lv LL. Service function assessment of river health based on plateau river ecosystem: A case study of Bahe River. Journal of Northwest A \& F University: Natural Science Edition, 2012, 40(9): 147-154, 160. [李朝霞, 朱洪蓉, 吕琳莉. 基于高原河流生态系统健康的服务功能评估: 以巴河为例. 西北农林科技大学学报: 自然科学版, 2012, 40(9): 147-154, 160.]

[18] The Qinghai-Tibet Plateau Comprehensive Scientific Expedition of Chinese Academy of Sciences ed. Tibet river and lake. Beijing: Science Press, 1984. [中国科学院青藏高原综合科学考察队. 西藏河流与湖泊. 北京: 科学出版社, 1984.]

[19] Wang LJ, Yu H, Niu Y et al. Distribution characteristics of water temperature and water quality of Fuxian Lake during thermal stratification period in summer. Chinese Journal of Environmental Science, 2017, 38(4): 1384-1392. [王琳杰, 余 辉, 牛勇等. 抚仙湖夏季热分层时期水温及水质分布特征. 环境科学, 2017, 38(4): 1384-1392.] 
[20] Zhang ZS, Huang XF ed. Research methods of freshwater plankton. Beijing: Science Press, 1995.[ 章宗涉,黄祥飞. 淡水 浮游生物研究方法. 北京: 科学出版社, 1995.]

[21] Chi NW ed. Atlas of Bacillariophyta in Tibet. Lhasa: Tibet People's Publishing House, 1990. [迟若文. 西藏硅藻图集. 拉萨: 西藏人民出版社, 1990.]

[22] The Qinghai-Tibet Plateau Comprehensive Scientific Expedition of Chinese Academy of Sciences ed. Tibet algae. Beijing: Science Press, 1992. [中国科学院青藏高原综合科学考察队. 西藏藻类. 北京: 科学出版社, 1992.]

[23] Zhu HZ, Chen JY ed. Bacillariophyta of the Xizang Plateau. Beijing: Science Press, 2000. [ 朱蕙忠, 陈嘉佑. 中国西藏 硅藻. 北京: 科学出版社, 2000.]

[24] Hu HJ, Wei YX eds. Chinese freshwater algae—system, classification and ecology. Beijing: Science Press, 2006. [ 胡鸿 钧, 魏印心.中国淡水藻类系统分类及生态. 北京: 科学出版社, 2016. $]$

[25] Sun J, Liu DY. Geometric models for calculating cell biovolume and surface area for phytoplankton. Journal of Plankton Research, 2003, 25(11) : 1331-1346. DOI: 10.1093/plankt/fbg096.

[26] Hillebrand H, Dürselen CD, Kirschtel D et al. Biovolume calculation for pelagic and benthic microalgae. Journal of Phycology, 1999, 35(2) : 403-424. DOI: 10.1046/j.1529-8817.1999.3520403.x.

[27] Kremer CT, Gillette JP, Rudstam LG et al. A compendium of cell and natural unit biovolumes for $>1200$ freshwater phytoplankton species. Ecology, 2014, 95(10) : 2984. DOI: 10.1890/14-0603.1.

[28] Padisák J, Barbosa F, Koschel R et al. Deep layer cyanoprokaryota maxima in temperate and tropical lakes. Advances in Limnology, 2003, 58: 175-199.

[29] Hu YM, Li QH, Zhu CC, et al. Contrasting phytoplankton structure based on functional groups of Puding Reservoir and Guijiahu Reservoir in the central of Guizhou Province. J Lake Sci, 2018, 30(2) : 403-416. DOI: 10.18307/2018.0212. [胡月敏, 李秋华, 朱冲冲等. 基于功能群对比分析黔中普定水库和桂家湖水库浮游植物群落结构特征. 湖泊科 学, 2018, 30(2): 403-416.]

[30] Huang L, Wang JB, Zhu LP et al. Water temperature and characteristics of thermal stratification in Nam Co, Tibet. J Lake Sci, 2015, 27(4) : 711-718. DOI: 10.18307/2015.0420. [黄磊, 王君波, 朱立平等. 纳木错水温变化及热力学分层 特征初步研究. 湖泊科学, 2015, 27(4): 711-718.]

[31] Cole GA ed. Textbook of limnology: Prospect heights. Illinois: Waveland Press, 1994.

[32] Huang YN, Ji DB, Long LH et al. The variance analysis of characteristics and blooms of the typical tributaries of the Three Gorges reservoir in spring. Resources and Environment in the Yangtze Basin, 2017, 26(3) : 461-470. DOI: 10.11870/cjlyzyyhj201703017. [黄亚男, 纪道斌, 龙良红等. 三峡库区典型支流春季特征及其水华优势种差异分析. 长江流域 资源与环境, 2017, 26(3) : 461-470.]

[33 ] Padisák J, Scheffler W, Kasprzak P et al. Interannual variability in the phytoplankton composition of Lake Stechlin ( 19942000). Advances in Limnology, 2003, 58: 101-133.

[34] Margalef R. Perspectives in ecological theory. Oikos, 1969, 20(2) : 571. DOI: 10.2307/3543237.

[35] Shannon CE, Weaver W, Wiener N. The mathematical theory of communication. Physics Today, 1950, 3(9): 31-32. DOI: 10.1063/1.3067010.

[36] Simpson EH. Measurement of diversity. Journal of Cardiothoracic \& Vascular Anesthesia, 1949, 163(2) : 261.

[37] Lin J, Yan Q, Zhu JR et al. Analysis of thermocline and hypoxia off the Changjiang Estuary in late summer. Journal of Fisheries of China, 2014, 38(10): 1747-1757. [林军, 间庆, 朱建荣等. 长江口外海域夏末温跃层与底层水低氧现 象研究. 水产学报, 2014, 38(10): 1747-1757.]

[38] Yu Y, Liu DF, Yang ZJ et al. Vertical stratification characteristics of dissolved oxygen and phytoplankton in thousand-island lake and their influencing factors. Environmental Science, 2017, 38 (4): 1393-1402. DOI: 10. 13227/j. hjkx. 201606085. [俞焰, 刘德富, 杨正健等. 千岛湖溶解氧与浮游植物垂向分层特征及其影响因素. 环境科学, 2017, 38(4) : 1393-1402.]

[39] Zhang L, Li QH, Huang GJ et al. Seasonal stratification and eutrophication characteristics of a deep reservoir, Longtan Reservoir in subtropical area of China. Environmental Science, 2015, 36(2) : 438-447. DOI: 10.13227/j.hjkx.2015.02. 010. [张垒, 李秋华, 黄国佳等. 亚热带深水水库一一龙滩水库季节性分层与富营养化特征分析. 环境科学, $2015,36(2): 438-447$.]

[40] Chen XK, Guo YH, Feng Y et al. Impact of great flood on phytoplankton assemblages and their succession: A case study 
of Gaozhou Reservoir, Guangdong Province. J Lake Sci, 2014, 26(1) : 137-146. DOI: 10.18307/2014.0117. [ 陈修康, 郭跃华, 冯喻等. 特大洪水对浮游植物群落及其演替的影响一—广东高州水库为例. 湖泊科学, 2014, 26(1): 137-146. ]

[41] Li J, Liang RF, Deng Y et al. Flow field of thermally stratified reservoir. Journal of Tianjin University: Science and Technology, 2014, 47(5) : 395-400. [李嘉, 梁瑞峰, 邓云等. 水库水温分层的流场分析. 天津大学学报: 自然科学与 工程技术版, 2014, 47 (5): 395-400.]

[42] Zhang SJ, Peng WQ. Water temperature structure and influencing factors in Ertan Reservoir. Shuili Xuebao, 2009,40 (10)：1254-1258. [张士杰, 彭文启. 二滩水库水温结构及其影响因素研究. 水利学报, 2009, 40 (10): 1254-1258.]

[43] Lu JS, Li ZL. Seasonal effects of thermal stratification on the water quality of deep reservoirs: A case study ofHeihe Reservoir, Xi' an City. J Lake Sci, 2014, 26(5) : 698-706. DOI: 10.18307/2014.0507. [ 卢金锁, 李志龙. 热分层对水库水 质的季节性影响——西安黑河水库为例. 湖泊科学, 2014, 26(5): 698-706.]

[44] Chen JA, Wang JF, Yu J et al. Eco-environmental characteristics of reservoirs in southwest China and their research prospects. Earth and Environment, 2017, 45(2): 115-125. [陈敬安, 王敬富, 于佳等. 西南地区水库生态环境特征与研 究展望. 地球与环境, 2017, 45(2): 115-125.]

[45] Huang TL, Zeng MZ, Qiu XP et al. Phytoplankton functional groups and their spatial and temporal distribution characteristics in a temperate seasonally stratified reservoir. China Environmental Science, 2016, 36(4) : 1157-1166. [黄廷林, 曾 明正, 邱晓鹏等. 温带季节性分层水库浮游植物功能类群的时空演替. 中国环境科学, 2016, 36(4) : 1157-1166.]

[46] Sun WZ, Wu DJ, Pei HY et al. Phytoplankton community structure and environmental factors in a newly built reservoir, Shandong Province. J Lake Sci, 2019, 31(3) : 734-745. DOI: 10.18307/2019.0312. [孙文秀, 武道吉, 裴海燕等. 山 东某新建水库浮游藻类的群落结构特征及其环境驱动因子. 湖泊科学, 2019, 31(3): 734-745.]

[47] Tian ZB, Liu DF, Yao XJ et al. Effect of water temperature stratification on the seasonal succession of phytoplankton function grouping in Xiangxi bay. Resources and Environment in the Yangtze Basin, 2014, 23 (5) : 700-707. DOI: 10.11870/ cjlyzyyhj201405015. [田泽斌, 刘德富, 姚绪姣等. 水温分层对香溪河库湾浮游植物功能群季节演替的影响. 长江 流域资源与环境, 2014, 23(5): 700-707.]

[48] Liu X, Du GS, Zhang H et al. Phytoplankton and nutrient degree of water body in Miyun Reservoir. Research of Environmental Sciences, 2003, (1) : 27-29. DOI: 10.13198/j.res.2003.01.29.liux.007. [刘霞, 杜桂森, 张会等. 密云水库的 浮游植物及水体营养程度. 环境科学研究, 2003, (1) : 27-29.]

[49] Li QH, Han BP. Structure and dynamics of phytoplankton community based CCA analysis in a pumped storage reservoir. Acta Ecologica Sinica, 2007, 27 (6) : 2355-2364. [李秋华, 韩博平. 基于 CCA 的典型调水水库浮游植物群落动态特 征分析. 生态学报, 2007, 27(6): 2355-2364.]

[50] Niu Y, Kong XH, Yu H et al. Spatial distribution of phytoplankton community during summer stratification in Lake Fuxian. Chinese Journal of Ecology, 2016, 35(7): 1865-1871. [牛远, 孔祥虹, 余辉等. 抚仙湖夏季热分层时期浮游植 物空间分布特征. 生态学杂志, 2016, 35(7): 1865-1871.]

[51] Zeng MZ, Huang TL, Qiu XP et al. Seasonal stratification and the response of water quality of a temperate reservoirZhoucun reservoir in north of China. Environmental Science, 2016, 37(4) : 1337-1344. DOI: 10.13227/j.hjkx.2016.04. 019. [曾明正, 黄廷林, 邱晓鹏等. 我国北方温带水库一一周村水库季节性热分层现象及其水质响应特性. 环境 科学, 2016, 37(4): 1337-1344.]

[52] Chen N, Wang Y, Yang T et al. Characteristics of functional group and evaluation of water quality of summer phytoplankton in the Tai Lake. Journal of Northeast Forestry University, 2018, 46(3): 69-73. [陈楠, 王芗, 杨天雄等. 泰湖夏季 浮游植物功能群特征及水质状况. 东北林业大学学报, 2018, 46(3): 69-73.]

[53] Zhao XX, Fang T, Yang K et al. Community structure characteristics of phytoplankton and related environmental factors in summer in Tuohu Lake, Anhui, China. Plant Science Journal, 2018, 36(5): 687-695. [ 赵秀侠, 方婷, 杨坤等. 安徽沱 湖夏季浮游植物群落结构特征与环境因子关系. 植物科学学报, 2018, 36(5): 687-695.]

[54] Li H, Liu Y, Fan YW et al. Community structure characteristics of phytoplankton in Tongjiang of the Sanjiang Plain wetland. Chinese Bulletin of Botany, 2014, 49(4) : 440-449. DOI: 10.3724/SP.J.1259.2014.00440. [李慧, 刘妍, 范亚文 等. 三江平原湿地同江地区水域夏季浮游植物群落结构特征. 植物学报, 2014, 49(4)：440-449.]

[55] Min WW, Wang PP, Li LJ et al. Relationship between phytoplankton functional groups and environmental factors in the 
Wei River Basin. Research of Environmental Sciences, 2015, 28(9): 1397-1406. [闵文武, 王培培, 李丽娟等. 渭河流 域浮游植物功能群与环境因子的关系. 环境科学研究, 2015, 28(9) : 1397-1406.]

[56] Feng Y, Xiao LJ, Wei GF et al. Responses of phytoplankton community to increasing water level in the lacustrine zone near the dam of a large tropical reservoir: Gaozhou Reservoir, South China. Chinese Journal of Applied and Environmental Biology, 2014, 20(3) : 529-536. DOI: 10.3724/SP.J.1145.2014.09033. [冯喻, 肖利娟, 韦桂峰等. 高州水库水位上 升期坝前深水区浮游植物群落的响应特征. 应用与环境生物学报, 2014, 20(3): 529-536.]

[57] Qi M, Wu JW, Gong SS et al. Relationship between characteristics of phytoplankton functional groups and their environmental factors in Changhu Lake. Oceanologia et Limnologia Sinica, 2020, 51 ( 1 ): 75-84. DOI: 10. 11693/hyhz20190700150. [祁梅, 吴嘉伟, 龚森森等. 长湖浮游植物功能群特征及其与环境因子的关系. 海洋与湖沼, $2020, \mathbf{5 1}(1): 75-84$.

[58] Xia YF, Hu XD, Xu JX et al. Seasonal succession of phytoplankton functional group and assessment of water quality in Lake Taihu. J Lake Sci, 2019, 31(1) : 134-146. DOI: 10.18307/2019.0113. [夏莹霏, 胡晓东, 徐季雄等. 太湖浮游 植物功能群季节演替特征及水质评价. 湖泊科学, 2019, 31(1) : 134-146.]

[59] Yang WH, Shen H, Zhou ML et al. Ecological characteristics of dominant phytoplankton community in Lake Nanhai (Baotou ) during freezing-thawing period. J Lake Sci, 2020, 32(2): 450-461. DOI: 10.18307/2020.0214. [杨文焕, 申涵, 周明利等. 冻融期包头南海湖浮游植物群落及优势种生态特征. 湖泊科学, 2020, 32(2) : 450-461.] 